\title{
Enhanced Immunoprecipitation Techniques for the Identification of RNA Binding Protein Partners: \\ CRD-BP interactions in mammary epithelial cells
}

\author{
Saja A. Fakhraldeen ${ }^{1 * \propto}$, Scott M. Berry ${ }^{2 * \#}$, David J. Beebe ${ }^{2}$, \\ Avtar Roopra $^{3}$, Vladimir S. Spiegelman ${ }^{4}$ and Caroline M. Alexander ${ }^{1}$ \\ ${ }^{1}$ McArdle Laboratory for Cancer Research, ${ }^{2}$ Department of Biomedical Engineering, \\ ${ }^{3}$ Department of Neuroscience, University of Wisconsin-Madison and \\ ${ }^{4}$ Department of Pediatrics, Division of Pediatric Hematology/Oncology, \\ Pennsylvania State University College of Medicine
}

* Equal first authors

\section{Corresponding author:}

Caroline Alexander cmalexander@wisc.edu

McArdle Laboratory for Cancer Research

Wisconsin Institutes for Medical Research, Tower2

University of Wisconsin-Madison

1111 Highland Ave

Madison WI 53703-2276

608-265 5182

${ }^{\propto}$ Current address: Kuwait Institute for Scientific Research, Kuwait City

${ }^{\#}$ Current address: Department of Mechanical Engineering, University of Kentucky

Running title: Enhanced immunoprecipitation of RNA binding proteins

Abbreviations: ESP ${ }^{\mathrm{TM}}$, exclusion-based sample preparation; IFAST ${ }^{\mathrm{TM}}$, Immiscible Filtration Assisted by Surface Tension; SLIDE ${ }^{\mathrm{TM}}$, Sliding Lid for Immobilized Droplet Extractions; RBP, RNA binding protein; RIP, RNA immunoprecipitation; RNP, ribonucleoprotein; PMPs, paramagnetic particles; CRD-BP, coding region determinant-binding protein; IMP1, insulin-like growth factor-2 mRNA binding protein 1; PAR-CLIP, photoactivatable-ribonucleoside-enhanced cross-linking and immunoprecipitation. 


\section{Acknowledgements}

Our appreciation to Celia Bisbach and Josh Martin for their technical assistance, and to Gilson Inc (Madison WI) for their gift of the EXTRACTMAN device. SAF was supported by the Kuwait Foundation for the Advancement of Sciences under project 2013-6302-03. This project was also supported by a DOD Scholar Award W81XWH-06-1-0491 (CMA), NINDS R21NS095187 (AR), NCI R01CA186134 (DJB) and NIAMSRO1AR063361 and NCI-RO1CA121851 (to VSS). This work was also supported in part by pilot funding from the NIH/NCI P30 CA014520--UW Comprehensive Cancer Center Support.

\section{Conflict of interest statements}

Scott M. Berry holds equity in, and is employed by, Salus Discovery LLC, which has licensed technology described in this manuscript. David J. Beebe holds equity in Bellbrook Labs LLC, Tasso Inc., Stacks to the Future LLC, Lynx Biosciences LLC, Onexion Biosystems LLC and Salus Discovery LLC.

Author contributions: CMA, SMB and SAF designed research; SAF performed research; AR, SMB and DJB contributed devices, analytic tools and bioinformatic expertise; AR, CMA, VSS and SAF analyzed data; CMA and SAF wrote the paper.

Keywords: Ribonucleoprotein immunoprecipitation (RIP); CRD-BP/IMP1/VICKZ1; exclusion-based sample preparation (ESP); PAR-CLIP 


\begin{abstract}
RNA binding proteins (RBPs) regulate expression of large cohorts of RNA species to affect programmatic changes in cellular phenotypes. In order to describe the function of RBPs within a cell, it is key to identify their mRNA binding partners. This is often done by cross-linking nucleic acids to RBPs, followed by chemical release of the nucleic acid fragments for analysis. However, this methodology is lengthy, involves complex processing leading to extraordinary losses, requires large amounts of starting materials, and is prone to artifacts due to the labile nature of mRNA. To evaluate potential alternative technologies, we tested "exclusion-based" purification of immunoprecipitates (oil-based IFAST $^{\mathrm{TM}}$ or air-based SLIDE ${ }^{\mathrm{TM}}$ ), and report here that these methods can efficiently, rapidly and specifically isolate RBP-RNA complexes with minimal handling. The analysis starts with $>100 x$ less material than for techniques that include cross-linking. Depending on the specific antibody used, 50-100\% of starting protein is retrieved, allowing the assay of endogenous levels of RBP instead of tagged and over-expressed ectopic proteins. Isolated protein and nucleic acid components are purified and analyzed using standard techniques to provide a comprehensive portrait of RBP complexes. Using exclusionbased techniques, we show that the mRNA binding partners for CRD-BP/IMP1/IGF2BP1/ZBP1 in cultured mammary epithelial cells are enriched in mRNAs important for de-toxifying superoxides (glutathione metabolic enzymes) and other mRNAs encoding mitochondrial proteins.
\end{abstract}




\section{Introduction}

RNA binding proteins (RBPs) are critical post-transcriptional regulators of gene expression in normal and pathological cellular contexts (1). At least 1542 RBPs govern RNA metabolism at myriad stages of splicing, export, storage, transport and translation (2). Often, RBPs bind select RNA species to modulate their expression, localization and/or stability, occasionally via highly specific and conserved sequence motifs. However, more typically, RBPs bind RNA species via short and degenerate sequences that are not easy to recognize prospectively (1).

Aberrant RBP activity is responsible for such important phenotypes as Fragile $\mathrm{X}$ syndrome (via the RBP FMRP) (3), and splicing reactions of cancer-associated tumor drivers, such as AR (via the RBP DDX3) (4). It is therefore important to define the cohort of mRNA binding partners that are bound by each specific RBP, since these are likely to be affected by altered RBP expression or activity. The cohort of mRNA species bound by a given RBP can be highly cell type-specific, for reasons that are not yet understood. RBPs sometimes stabilize mRNA species; this is deduced from the demonstration of a direct binding interaction, together with decreased abundance upon RBP knockdown/knockout $(1,5)$. However, other regulatory activities that do not result in altered RNA abundance are much more difficult to identify, for example regulation of RNA localization and delivery of target proteins to specific subcellular structures (6). It may be possible to evaluate these partnerships from a catalog of specific mRNA binding partners, for example the adhesion defects observed by Conway et al (7) for CRD-BP/IMP1 knockdown embryonic stem cells.

Most studies rely upon UV-induced cross-linking coupled with immunoprecipitation techniques to define mRNA binding partners for RBPs. By exploiting the unique chemical reactivity of RNA for protein, irreversible cross-links can be formed between RNA and protein moieties that lie in close proximity (1). This technique was widely adopted after concerns were raised about the potential for switching of RBP binding partners during incubations (8). However, it is not trivial to reverse these cross-links sufficiently to release and identify the bound mRNA species, and the yield of input RBP that emerges after the extensive processing reactions is substantially less than $1 \%$ of total (9). Various versions of photoactivatable-ribonucleosideenhanced crosslinking and immunoprecipitation (PAR-CLIP) protocols have been described and applied to the analysis of RBPs; the strengths and weaknesses of each have been reviewed (5, 9-12). In general, the limitations of cross-linking protocols fall into various classes: the loss of unstable RNA species during long processing procedures, loss of mRNAs with indirect or low affinity interactions during washing of immunoprecipitates, artifacts created by cross-linking and extensive derivatization processes, and the requirement for an impractically high starting numbers of labeled cultured cells over-expressing the RBP of 
interest. Indeed, in many key cell types, RBP interactions cannot be studied due to the requirement for up to $1 \mathrm{~g}$ of starting protein lysate. Here, we have applied two exclusion-based sample preparation $\left(\mathrm{ESP}^{\mathrm{TM}}\right)$ technologies to identify mRNA binding partners for an exemplar RBP; the simple, expedited processing that is required for the techniques used in this paper versus those required for PAR-CLIP are summarized in Fig. 1.

The focus of this study is the RNA binding protein $\underline{\text { Coding- }}$ egion $\underline{\text { Determinant }}$ Binding $\underline{\text { Protein }}$ (CRDBP), originally defined as a regulator of stability of Myc mRNA. CRD-BP has been independently identified as to protein responsible for several important activities, as reflected by its diverse set of names (including IMP1, IGF2 mRNA binding protein, gene name is IGF2BP1; ZBP1, zipcode binding protein-1, VICKZ1) (13-16). This protein is often highly expressed in tumor and fetal cells and is required for several tumor-associated activities in a wide range of cell types (17-21). We showed previously that both normal breast epithelial cells and breast tumor cells expressed relatively low levels of two forms of the CRD-BP protein; despite low expression, this protein regulated clonogenic growth of breast cancer cells in vitro (22). Indeed, CRD-BP has been shown to be required for clonogenic activity in several tumor cell types, suggesting that it enables some fundamental property required for clonogenic growth (23).

Target mRNAs bind the KH repeat domains of CRD-BP via combinatorial interactions through a looped tertiary structure with short consensus sequences. This complex interaction makes them difficult to predict $a$ priori $(24,25)$. To understand the molecular basis of important functional activities, we tested whether ESP technologies could isolate mRNA binding partners from the low levels of CRD-BP that are expressed by breast epithelial cells. This focused our attention on efficient retrieval of CRD-BP complexes. Exclusion based technologies have been deployed for many reasons, including their sensitivity, speed, parallel processing capacity and potential for multiple endpoint assays (26). The mRNA binding partners identified by this analysis included the mRNAs for glutathione metabolism, including the seleno-protein glutathione peroxidases Gpx1 and Gpx2 (important for the detoxification of superoxides (27)), and a group of mRNAs encoding proteins destined for mitochondria. We propose that this technology is a useful approach to dissecting RBP function, either alone, or as a complement to techniques requiring accurate binding site predictions that are typically derived from cross-linking studies.

\section{Materials and Methods}

\subsection{Cell culture and transfections}

Mouse embryonic fibroblasts (MEFs), the EP and EN sub-strains of the mouse mammary epithelial cell 
line HC11, 293T, MCF7 and MDA-MB-231 cells were cultured as previously described (22). A construct expressing Flag-tagged CRD-BP was described in a previous publication (28). Transfections were carried out using Lipofectamine LTX with plus reagent (Life Technologies) according to manufacturer's instructions.

\subsection{Ribonucleoprotein immunoprecipitation (RIP)}

Cells were cultured in $10 \mathrm{~cm}$ dishes and lysed in polysome lysis buffer (10 mM HEPES (pH 7.0), $5 \mathrm{mM}$ $\left.\mathrm{MgCl}_{2}, 100 \mathrm{mM} \mathrm{KCl}, 0.5 \% \mathrm{NP}-40\right)$ with freshly added DTT (1 mM), RNase (100 U/ml), and protease/phosphatase inhibitors (Thermo Fisher Scientific). Approximately $10^{6} 293 \mathrm{~T}$ cells (a single $10 \mathrm{~cm}$ dish at $\sim 80-90 \%$ confluence) yields $500 \mu \mathrm{l}$ of lysate, with approximate protein concentration $4 \mu \mathrm{g} / \mu \mathrm{l}$; RIP reactions were processed in batches of $200 \mu$. For other cell types, such as the breast epithelial cells described in these studies, $2 \times 10 \mathrm{~cm}$ dishes were processed into $500 \mu \mathrm{l}$ of lysis buffer. Lysates were sonicated (10 pulses at 4-5W) and cleared by spinning $3 \mathrm{x}$ at $12,000 \mathrm{rpm}$ for 30 minutes at $4^{\circ} \mathrm{C}$. Protein concentrations for the whole cell lysates and the unbound fractions were determined using Bradford reagent (Sigma-Aldrich). For immunoprecipitation, approximately $1.2 \mu \mathrm{gs}$ of specific primary antibody (or matched IgG control) were added, together with $5 \mu$ of washed protein G-bound paramagnetic Dynabeads (Life Technologies cat\#10003D). Antibody binding of RBP complexes was allowed to proceed at $4^{0} \mathrm{C}$ for the times indicated, before purification using IFAST, SLIDE-based or standard immunoprecipitation. The following antibodies were used: anti-CRDBP antibody (Cell Signaling cat\#8482; RRID:AB_11179079), anti-Flag antibody (Sigma-Aldrich cat\#F3165; RRID:AB_259529), or non-immune rabbit IgG control (Jackson Immunoresearch cat\# 011-000-003; RRID:AB_2337118). Following the RIP procedures, aliquots from the bound and unbound fractions were harvested and assayed for CRD-BP using Western blotting (to assess efficiency of extraction), and the remaining sample was used for RNA analysis.

\subsection{Western blotting}

Lysates were analyzed by SDS-PAGE followed by transfer to PVDF membranes, as described in (22). Primary antibodies: anti-CRD-BP (Cell Signaling cat\#8482; RRID:AB_11179079), diluted 1:1000; antivinculin (Millipore cat\#05-386; RRID:AB_309711) diluted 1:5000; anti-GAPDH (Cell Signaling cat\#2118; RRID:AB_561053) diluted 1:3000-1:5000. Secondary antibodies: HRP anti-mouse (Jackson Immunoresearch cat\# 715-035-151; RRID:AB_2340771); HRP anti-rabbit (Invitrogen cat\# G-21234 RRID:AB_2536530) diluted 1:5000 or HRP mouse anti-rabbit IgG (conformation-specific) (Cell Signaling cat\#L27A9; 
RRID:AB_10892860). All antibodies were diluted in 5\% milk in TBS-Tween.

\subsection{RNA isolation and analysis}

Total RNA was isolated using the RNeasy Mini Kit (Qiagen). RNA concentrations and quality were determined using a Nanodrop instrument (Thermo Scientific; average 260/280 ratio 2.1). Reverse transcription was performed as previously described, and specific mRNAs were quantified using q-RT PCR (29).

\subsection{Microarray analysis}

A Nimblegen 12-plex whole mouse genome microarray chip (Build 100718_MM9_EXP_HX12; comprising 44171 probes, equivalent to 24205 individual genes) was used to assay the relative abundance of each mRNA in cDNA libraries made from each sample. RNAs were processed for this analysis according to manufacturer's instructions; briefly, first strand followed by second strand cDNA synthesis was performed, followed by RNase cleanup, and cDNA precipitation. Double stranded cDNA (4 $\mu \mathrm{g}$ ) was Cy3-labeled and hybridized to microarray chips, which were then washed and scanned. For any given experimental condition, duplicate sets of four samples of cDNA were prepared for analysis by microarray: unbound and bound RNA from anti-CRD-BP immunoprecipitates, and from anti-IgG immunoprecipitates (specificity control) for analysis. The data was analyzed using Multi-Experiment Viewer (MeV) software.

\subsection{Bioinformatic analysis}

Raw intensity readings from the microarray analysis were log2-transformed and median-centered. These lists were rank-ordered, and the rank of genes determined for the mRNAs co-purifying with the paramagnetic particles (PMPs), for comparison with the ranking of genes in the unbound fractions. Statistical analysis of independent replicates was used to reflect the significance of fold changes, $p<0.01$. Enriched gene sets for RNAs pulled through by the specific antibody, anti-CRD-BP, were compared with the non-specific control, IgG fraction. The relative enrichment of RNA species in bound fractions was confirmed independently by qRTPCR. These confirmed mRNA species, accumulating in anti-CRD-BP immunoprecipitation reactions, were imported into pattern prediction algorithms, such as STRING (string-db.org).

\section{Results}

\subsection{Use of exclusion-based sample preparation (ESP) devices}




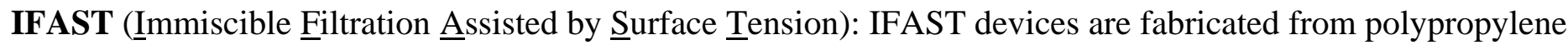
via injection compression molding (DTE Research and Design, LLC), and consist of linearly aligned wells (5$15 \mu \mathrm{l}$ volume) connected by trapezoidal microfluidic conduits (Fig. 2). These wells are flanked by a larger input well (up to $200 \mu \mathrm{l}$ volume) on one end, and an output well of designer-specified volume (5-10 $\mu 1)$ on the other. The pre-incubated cell lysate/antibody/paramagnetic particles (PMPs; prepared as described in Materials and Methods) mixture is transferred to the input well, and PMP-bound biomolecular complexes are purified by a magnet-based pull through the intermediate wells, which consist of alternating solutions of oil (Fluoinert FC-40 oil, Sigma-Aldrich), and aqueous wash phases, to the output well. Note that this requires no pipetting or additional handling beyond the initial loading of the device and takes an average of 20-30 seconds. The utility of this device for identifying valid biological interactions (including weak interactions), for streamlining multiplexed assays of analytes, and for the detection of viral RNAs for clinical diagnostics has been previously demonstrated (30-34).

SLIDE (ㅁliding Lid for Immobilized Droplet Extractions): In order to avoid the use of oil-based exclusion, we employed a SLIDE device, which depends instead on air-based exclusion (35). This has the advantage of eliminating oil from the purification process and the pull-through lysate. The SLIDE device consists of a handle and a base, each with movable magnets within them (35) (commercial name is EXTRACTMAN ${ }^{\mathrm{TM}}$ from Gilson). A polypropylene well plate (provided by Gilson, Inc.) is loaded with samples containing PMPs, wash buffer, and elution buffer. By sliding the SLIDE handle across the base, PMPs are rapidly and efficiently transferred between reagents in series. Importantly, PMPs are collected on a disposable PMP collection strip, which is comprised of highly polished uncharged polypropylene. Thus, this hydrophobic PMPs collection minimizes carryover of aqueous material as the SLIDE handle moves between reagents. In RIP experiments, the input wells of this device are loaded with cell lysate and the RBP-complex bound-PMP beads are moved through adjacent wells containing wash buffer as described above (Fig. 3); total time for exclusion purification is approximately 20 seconds.

By passing the PMPs carrying immunoprecipitation complexes through oil (IFAST) or air (SLIDE) by attraction to a magnet, the aqueous dead volumes are minimized, reducing the time and handling required to dilute out associated fluids (i.e. to wash immunoprecipitates). The internal aqueous volume of paramagnetic particles (PMPs) is approximately $115 \mathrm{nls}$ for each $5 \mu \mathrm{l}$ volume of beads. We optimized the protocol for this specific buffer composition, given that the residual surface volume determines surface tension (increased by higher salt and decreased by detergent). Samples were processed simultaneously for up to four immuno-PMP lysates (directly in parallel), whereas samples were processed individually in the IFAST devices. 


\subsection{Efficiency of purification of the RNA binding protein, $C R D-B P$}

We tested the efficiency of the recovery of endogenous CRD-BP protein by immunoprecipitation using IFAST, first for two cell types, 293T human embryonic kidney cells and mouse embryonic fibroblasts (MEFs), and then for a tagged CRD-BP protein (applying a different antibody, anti-FLAG) expressed in cultured mouse mammary epithelial cells (Fig. 4A, B) $(36,37)$. Using the anti-CRD-BP antibody to purify endogenous CRDBP from 293T cells and MEFs, the yield of purified protein was 50-60\% of total input; for the high affinity antiFLAG antibody, losses were insignificant. Vinculin was used as an indicator of non-specific protein adsorption, and was not detectable. We also tested the efficiency of the affinity purification by assaying residual antibody in the unbound fraction and found almost no losses for the immunocomplexes during extraction from the cell lysates (Fig. 4C).

We next evaluated the efficiency of recovery when shorter times were allowed for immunecomplexation. Maximal recovery was found for overnight incubation, but significant recovery was obtained using only 30 minutes of binding ( $24 \%$ for 30 minutes compared to $60 \%$ recovery for overnight complexation) (Fig. 4D). For unstable RNAs, these short preincubation times could be particularly important.

\subsection{Efficiency of immunoprecipitation of RNA with endogenous CRD-BP protein}

To evaluate the efficiency of recovery for cells with low endogenous levels of CRD-BP, we tested mouse mammary epithelial cells (EP cells). Although CRD-BP is typically 100x less expressed in cells derived from adults compared to fetal cells, CRD-BP is still functionally important, at least for the expression of clonogenicity in vitro (22). We showed that the efficiency of pull-through of CRD-BP by IFAST from mouse mammary epithelial cells (EP cells) was approximately the same as for the cell lines with high endogenous levels of CRD-BP (shown in Fig. 4), measured at $62 \%$ by Western blotting (Fig. 5A).

Using the IFAST protocol, 5-fold more RNA was pulled through with the CRD-BP immunocomplexes than with the control (IgG) bound PMPs (1.1\% compared to $0.2 \%$ for anti-IgG) (Fig. 5A). A "standard" immunoprecipitation protocol without cross-linking was compared with IFAST-purified RIP complexes; in other words, we used typical serial pipetting operations to conduct sequential, manual washes of each immunoprecipitate-bound PMP sample in individual Eppendorf tubes. We found broadly similar efficiency for recovery of both RBP protein and the total associated RNA (Fig. 5B).

We also tested whether the RNAs pulled through by this enhanced immunoprecipitation protocol 
included mRNA binding partners previously characterized as CRD-BP/IMP1 binding partners in 293T cells (36). All ten mRNA species surveyed were significantly pulled through by SLIDE-RIP (Fig. 5C).

\subsection{Analysis of the CRD-BP mRNA complexes from mouse mammary epithelial (EP) cells}

Ranked gene lists of bound and unbound mRNA fractions were compared for CRD-BP and IgG control IFAST-purified RIP fractions, to identify species that showed a significant change in rank listing ( $\mathrm{p}<0.01)$. The CRD-BP gene list included 1,343 genes, of which 443 (approximately 35\%) overlapped with the gene list from IgG control fractions (1,170 genes). These "sticky mRNAs" were subtracted from the total to generate a list of 900 potentially specific mRNAs in CRD-BP-associated complexes.

The fold enrichment of these 900 mRNA species (all >2-fold) is illustrated in Fig. 6A, and the mRNAs most highly enriched are shown as Fig. 6B (>4-fold). To verify the array analysis of RIP fractions, we selected $>30$ mRNA species for evaluation by qRT-PCR, including enriched and excluded mRNAs (Fig. 6C). For the purpose of illustration, we set a threshold on this confirmation assay; this threshold excludes $93 \%$ of mRNAs not enriched by array analysis, and also increases the stringency of inclusion in the specifically enriched fraction.

To test whether this group of genes includes mRNAs associated with related cellular processes, we analyzed the group of 900 genes by STRING analysis (Fig. 7). We found significant enrichment of genes involved in glutathione metabolism, including glutathione peroxidase-2 (Gpx2), which catalyzes the reduction of organic hydroperoxides and $\mathrm{H}_{2} \mathrm{O}_{2}$ by glutathione, protecting cells against oxidative damage. Also enriched were glutathione S-transferases of the mu, theta and omega classes (Gstm1, -5, Gstt1 and Gsto2), involved in detoxification of electrophilic compounds (including carcinogens, therapeutic drugs, environmental toxins and products of oxidative stress by conjugation with glutathione microsomal glutathione-S-transferase), and microsomal glutathione S-transferase (Mgst3) involved in the production of leukotrienes and prostaglandin E. Another group includes core components of DNA synthesis. The other two groups enriched in this complex reflect mRNAs that are made in the nucleus and are translated proximal to the mitochondrion (38), including the mitochondrial ribosomal components (labeled mitochondrial translation) and complex 1-associated mRNAs of the electron transport chain that are not made by the mitochondrion (labeled Complex 1). The gene lists identified by these analyses are provided as supplemental data (Table S1).

\subsection{Corresponding mRNAs were pulled through in CRD-BP-associated complexes from breast tumor cells}


By way of preliminary validation of these results in human breast cancer cells, lysates of MCF7 and MDA-MB-231 cells were purified by anti-CRDBP RIP-SLIDE, showing a protein purification efficiency of approximately $47 \%$ for MCF7 cells, together with a yield of $2.6 \%$ mRNA. This included over 7-fold enrichment (CRD-BP/IgG) and >25\% total yield of GPX1 (glutathione metabolism), MRPS16, MRPL14 and TIMM10 (mitochondrial targeted mRNAs), compared with $<7 \%$ yield of excluded mRNA species (TAOK1 and ETNK1) (Fig. 8).

\section{Discussion}

4.1. The application of ESP to the discovery of RNA binding partners for proteins. Exclusion-based sample preparation (ESP) has been shown to be useful for cell, DNA and protein isolation from complex biological samples $(35,39,40)$. The main time and labor-saving aspects of ESP methods are the substitution of the standard, manual pipetting operations with a swift, coordinated wash via magnetized bead adsorption. There can be profound impact of this technology, since increasing the speed of purification promotes the identification of more weakly bound or labile complex components (30). This may particularly apply to RNA-protein interactions, since the potential for exchange during the rapid wash procedure applied with ESP technologies is low. The potential for exchange of interactors was one of the drivers for development of cross-linking technologies to the study of RBP complexes. These concerns arose from a letter to the editor of RNA in 2004 which showed that 90 mins of co-incubation of a lysate containing an RNA binding protein (HuR) together with a cell lysate containing a known specific binding partner, the fos mRNA species, was more than enough to promote their interaction (8). We showed in a previous publication that dissociation of an antibody/protein complex increased from zero to $80 \%$ dissociation during a timecourse of 100 minutes (30). Only 10 minutes in a moderate salt wash buffer promoted $50 \%$ complex dissociation, but one minute showed insignificant losses, and importantly, the specificity of the wash was maintained. Therefore, the timescale for the ESP purification (on the order of seconds) prevents re-association artifacts.

4.2. Summary of advantages of ESP over RIP-ChIP and CLIP technologies. Techniques for identifying the RNAs that associate with specific RBPs have become increasingly sophisticated $(10,41,42)$. However, the downsides of crosslinking of RNA to RBP have been noted before in a publication that showed optimal isolation conditions for a classic "RIP-ChIP" (43). A summary of the processing aspects of the ESP-based 
technologies, IFAST and SLIDE, versus one of the examples of CLIP technologies, PAR-CLIP (44-47), is shown in Figure 1.

We summarize these potential advantages of ESP:

i. Almost quantitative yields. The amount of pull-through of any given RBP is related to the avidity of the antibody for the protein of interest (shown by the almost quantitative extraction of a Flag-tagged version of CRD-BP by the high-avidity anti-Flag antibody, Fig. 4B). For the anti-CRD-BP antibody, the total yield is approximately $60 \%$ of total. Unlike previous RIP studies, we can claim to examine the binding interactions of the majority of RBP protein, instead of $<1 \%$ of total (48). This also offers the opportunity to study endogenous level proteins, where the exogenous expression of RBPs can be mis-localized (36).

ii. Starting amounts of lysate. The amount of starting material required is over 100x less than for a typical CLIP procedure, given there are virtually no losses. Indeed, the sensitivity could be enhanced still further, depending upon the output required. This is especially important for human samples and samples of purified or limiting cells of any source (such as subpopulations of tumor cells or stem cell populations).

iii. No mechanistic bias is required. The underlying assumption of cross-linking technologies is that RBPs require direct contact with mRNA binding partners to affect their stability, delivery or translation. However, mechanistically, this may not be correct, and the isolation of RNA immunoprecipitates by ESP does not require direct contact. For example, any given RBP may be required for the assembly or stability of ribonucleoprotein super-molecular complex granules with sequestered RNA species (49). Thus, although there is value in understanding the precise sites for RNA interaction (for example for FMRP (50)), this is not always necessary. iv. Parallel handling and rapid processing. Prior characterization of the performance of the ESP devices has shown that specific but low-affinity reactions are preserved by rapid pull-through of magnetic beads through air or oil. This enhances the typical RIP-ChIP protocols by offering an expedited processing procedure, making the starting material less prone to degradation, and requiring less handling, which makes loss of key species during wash procedures less likely.

Note that the results of this assay are limited by the nature of the analysis of the complex components; here the results are restricted to probes that appeared on the micro-arrays, eliminating important regulatory nonmRNA species such as lncRNA, ncRNA or miRNAs. However, this technique is entirely compatible with other techniques such as RNA-Seq, or targeted arrays, which would reveal these species. It is also dependent upon the antibodies used for immunoprecipitation: for example, antibodies previously reported to identify CRD- 
BP/IGF2BP1 partners did not pass our validation criteria $(7,51)$. Furthermore, mass spectrometry is entirely compatible with ESP-RIP, allowing a full dissection of protein components of RBP particles.

\subsection{Comparison of the results of ESP purification of CRD-BP binding RNAs with other studies.}

CRD-BP has been implicated in a variety of aspects of mRNA metabolism and expression, from the stabilization of mRNAs by blocking miRNA binding sites $(52,53)$, to the localization or translation of cognate proteins $(54,55)$. Functionally, this protein it is important to cell survival, cell migration and chemo-resistance (56-59), and this underlies the focus on determining its mechanism of action.

There are parallel data for several types of RIP analyses of CRD-BP in different cell types; the results of five studies, including this one, are shown in Table $1(7,36,37,60)$. Nielsen and colleagues exogenously expressed Flag-tagged CRD-BP to determine potential mRNA interactions in 293T cells; they found that CRDBP associates with a considerable proportion of the total transcriptome (3\%) in large 100-300 nm intracellular granules (36). The study started with 100x more cell lysate, and did not report total yields (Jonson et al., 2007). Overall, the results showed 352 specific mRNA species associated with CRD-BP, which is in the same order of magnitude as our study, where our study relied on the low endogenous expression in mouse mammary cells as the immunoprecipitation target. Furthermore, assay of mRNA binding partners identified by Jonson et al confirmed that these were also enriched in CRD-BP associated RNA populations from mammary epithelial cells in this study (Fig. 5C).

This contrasts with the lack of consensus from the published CLIP studies of CRD-BP: thus, the data sets derived from PAR-CLIP / 293T cells (37) and eCLIP / human embryonic stem cells (7) showed little overlap between gene sets derived from either CLIP technology and those derived from RIP (Jonson et al or this study). Specifically, there were only 6 matching mRNAs for the large libraries identified as CRD-BP binding partners in 293T cells $(36,37)$, and 17 matches between human 293T cells and this study of mouse mammary epithelial cells (36). This is despite shared expression of many of the mRNA species identified as CRD-BP partners. CLIP cross-linking techniques include sophisticated statistical arguments to identify significant rates of association of specific RNA sequences, leading Hafner et al to identify 56 unique mRNAs from RIP isolates of 293 T cells transfected with tagged CRD-BP; the catalog of mRNAs identified in RIP isolates of human embryonic stem cells were not specified (7). The latter study states there was no overlap between the eCLIP gene set and the genes identified by the RNA Bind-n-Seq technique described by Lambert et al (61), or between those gene lists and the mRNAs destabilized by knockdown of CRD-BP. The reasons for the lack of overlap 
between the parallel techniques used in these studies is not yet understood and could be important to resolve. Note that CRD-BP was originally isolated as the protein protecting c-Myc mRNA from degradation in K562 cells $(16,53,62)$, but this association is not necessarily typical of other cell types, despite widespread expression of c-Myc.

We are intrigued by the enrichment of mRNAs for proteins destined to be imported into mitochondria (63) and for components of the glutathione metabolism pathway $(27,64)$. There is a well-established partnership between regulated RBP activity and mitochondrial mRNA translation and import (38).

Mitochondrial function in turn is an important determinant of clonogenic survival and establishment, which are consistent markers of CRD-BP activity $(65,66)$. For example, the RBP CLUH (clustered mitochondria homologue), together with other RBPs, have been shown to regulate the expression of a mitochondrial protein network that become important under conditions of nutrient deprivation (67). Glutathione metabolism is key to the disposition of super-oxides, which are produced at high levels during chemotherapy (68). CRD-BP and its close paralogue, IGF2BP3, have beeen shown to enhance drug resistance for tumor cells $(69,70)$. However, we note that the specific gene ontology keywords differ for this study of mouse mammary epithelial cells and for the 293 T cells described by Jonson et al (proteins involved in secretory pathway and endoplasmic reticulumassociated quality control, as well as ubiquitin-dependent metabolism), and the verification of the actual activity of CRD-BP awaits functional evaluation in cell types that show important CRD-BP dependent phenotypes.

\section{Conclusions}

We have demonstrated the application of a simple enhanced RNA immunoprecipitation procedure that enables parallel processing with highly efficient retrieval of specific RBP-associated mRNAs. This procedure can be applied to limiting amounts of experimental materials. This increases the currently available technologies that can be applied to this field of research and offers the opportunity to evaluate alterations of RBP-associated species under numerous experimental conditions, that is not feasible by other means. Our preliminary analysis of the RBP, CRD-BP/IMP1, in cultured mouse mammary epithelial cells reveals intriguing links to functional components of cancer cell metabolism.

\section{Acknowledgements}

More information on the application of these SLIDE devices is presented in video form at https://www.gilson.com/extractman-starter-kit.html. 
bioRxiv preprint doi: https://doi.org/10.1101/2021.06.10.447893; this version posted June 10, 2021. The copyright holder for this preprint (which was not certified by peer review) is the author/funder, who has granted bioRxiv a license to display the preprint in perpetuity. It is made available under aCC-BY-NC 4.0 International license. 


\section{Figure Legends}

Figure 1. Comparison of ESP and (PAR-)CLIP technologies. Schematics of the workflow for ESP methodology (A) compared to PAR-CLIP (B), as performed by Hafner et al (37), to illustrate one of the incentives for performing this study. Specifically, the timeline and handling required for both procedures is shown on clock faces, together with the relative amounts of starting cell lysate required, and the complexity of the PAR-CLIP protocol. Typically, RBPs are over-expressed for CLIP protocols. * indicates the use of nucleoside substitution, which can induce a nucleolar stress response and result in cytotoxicity $(71,72)$.

\section{Figure 2. Overview of ESP-based Immiscible Filtration Assisted by Surface Tension (IFAST). A.}

Schematic of RIP-IFAST technique; the purification (or "exclusion") phase of the ribonucleoprotein immunoprecipitation process is provided by pulling magnetic beads loaded with immunoprecipitate through a lipid barrier located between aqueous wells. B. An overview of the IFAST protocol, showing the configuration and dimensions of the device.

Figure 3. Overview of ESP-based Sliding Lid for Immobilized Droplet Extraction (SLIDE). A. Schematic of SLIDE ${ }^{\mathrm{TM}}$ technique using EXTRACTMAN ${ }^{\mathrm{TM}}$ device (Gilson, Inc.). The exclusion phase operates by repeated cycles of lifting of magnetic beads loaded with immunoprecipitate out of the wash solution. The extracted drops are held against a hydrophobic surface with minimum aqueous volume and surface tension prior to re-elution in a fresh aqueous solution. B. An overview of the SLIDE protocol, showing the configuration and dimensions of this specific device.

\section{Figure 4. Efficiency of pull-through of CRD-BP protein using IFAST. A. Demonstration of efficiency of} pull-through of endogenous CRD-BP. Two cell types with high levels of endogenous CRD-BP (293T and MEF) were lysed, incubated with anti-CRD-BP primary antibody and protein G paramagnetic particles (PMPs), and RIP fractions purified using IFAST. A known amount (typically 20\%) of total immunoprecipitate pulled through was analyzed by Western blotting (bound) and compared to the input remaining (unbound), with whole cell lysate (before pull-through; WCL) shown for comparison. Vinculin is used to evaluate specificity of the immunoprecipitation. The fraction of CRD-BP pulled through is shown below (\%). B. Comparison of efficiency of pull-through of tagged CRD-BP. Mouse mammary cell lines, EP and EN cells, were transfected with Flagtagged CRD-BP (or empty vector, mock). 48 hours later, lysates were purified using IFAST. C. Evaluation of 
efficiency of pull-through of antibody-PMP particles using IFAST. For the cell lysates indicated, the amount of IgG remaining in the unbound fraction was assessed by Western blotting with conformation-sensitive anti-IgG antibody. D. Evaluation of efficiency of immunoprecipitation with time. 293T cell lysates were incubated with anti-CRD-BP antibody or an IgG control and paramagnetic particles for varying lengths of time (overnight (O/N), 2 hours, or 30 minutes) prior to purification either by standard or SLIDE-based RIP. Pull-through efficiency was evaluated by Western blotting.

\section{Figure 5. Immunoprecipitation of RNA in RIP CRD-BP complexes isolated by ESP methods. A.}

Determination of amount of RNA in IFAST RIP. Mouse mammary epithelial (EP) cell lysates were incubated with anti-CRD-BP antibody or an IgG control, and immunoprecipitates purified using RIP-IFAST. The protein component of the immunoprecipitate was analyzed by Western blotting as for Figure 4. RNA was purified and the amount of RNA in each fraction was determined. B. Side-by-side comparison of RNA purification by standard and SLIDE RIP. 293T cell lysates were incubated with anti CRD-BP $1^{\circ} \mathrm{Ab}$ or an IgG control, and lysate + antibody mixtures were purified using either standard or SLIDE -based RIP. The efficiency of pullthrough of CRD-BP $(\mathrm{n}=3)$ and associated RNAs $(\mathrm{n}=2)$ is shown. C. Validation of SLIDE-enriched mRNA partners. Selected RNA species identified in Flag-tagged CRD-BP-associated RNP particles by Jonson et al (36) were evaluated by qPCR of SLIDE-enriched RIP fractions of endogenous CRD-BP from 293T cells.

Figure 6. Analysis of RNA binding partners for CRD-BP in mouse mammary epithelial cells (EP cells).

A. General enrichment of bound $m R N A s$. The relative fold-enrichment of 900 genes judged as specifically enriched in the anti-CRD-BP complexes $(\mathrm{p}<0.01)$ purified by IFAST-RIP from EP cells. B. Most enriched mRNA species. The mRNA species $>4 \mathrm{x}$ enriched are shown as a detail of panel A. C. Confirmation of mRNAs pulled through in functional groupings. Functional groupings are shown diagrammatically in Fig. 7. To confirm enrichment scored from array analysis, a subset of associated mRNAs were tested by qRT-PCR analysis. For this study, a set of $31 \mathrm{mRNAs}$ comprising 17 specifically and significantly enriched in the CRDBP-bound fraction (green), were compared to 14 mRNAs specifically excluded from the CRD-BP-bound fraction (red). A potential thresholding line is drawn, that excludes $93 \%$ of mRNAs not enriched by array analysis and includes $64 \%$ of mRNAs designated as enriched.

\section{Figure 7. Functional grouping of mRNAs in CRD-BP complexes from mouse mammary epithelial (EP)}


cells. A. The mRNAs in control IgG complexes were subjected to STRING analysis, which found no significant enrichment groups except for a (relatively unique) group of histone mRNAs, and intriguingly, the mRNA for CRD-BP itself. B. The mRNAs in CRD-BP-associated complexes showed functional enrichment for 4 groups of genes, glutathione metabolism genes (including Gpx2), mRNAs related to transcription, and mRNAs for proteins targeted to mitochondria, important for mitochondrial ribosome function and the assembly of complex 1 in the electron transport chain.

\section{Figure 8. Confirmation of ROS-detoxifiers and mitochondrial mRNAs amongst CRD-BP binding targets} in breast cancer cell lines. A. Comparison of RNA targets enriched by SLIDE processing of CRD-BP RIP from breast cancer cell lines. MCF7 and MDA-MB-231 human breast cancer cell lysates were incubated with anti-CRD-BP antibody or an IgG control, and the lysate + antibody mixtures were subjected to purification by SLIDE (as per Figure 4) and the efficiency of pull-through of CRD-BP protein and RNA binding partners was calculated. Six mRNAs were assayed by qRT-PCR, including four specifically associated in RIP fractions of mouse mammary epithelial cells, and two excluded from these fractions (TAOK1 and ETNK1; Fig. 6). 
Table 1. Comparison of RNA associations for CRD-BP defined by different RIP techniques. The experimental conditions are listed that relate to approach, cell background and outcomes of each technique.

\begin{tabular}{|c|c|c|c|c|c|c|}
\hline & Method & $\begin{array}{l}\text { Scale/ } \\
\text { Cell type }\end{array}$ & \begin{tabular}{|l|} 
CRD-BP \\
target
\end{tabular} & $\begin{array}{l}\text { RNA cross- } \\
\text { link / RNA } \\
\text { labeling }\end{array}$ & Assay & $\begin{array}{l}\text { Proportion of CRD-BP } \\
\text { retrieved for analysis; } \\
\text { number of RNA binding } \\
\text { partners }\end{array}$ \\
\hline $\begin{array}{l}\text { Jonson } \\
\text { et al } 2007 \\
(36)\end{array}$ & RIP & $\begin{array}{l}1.20 \times 10^{8} \\
293 \mathrm{~T} \text { cells }\end{array}$ & $\begin{array}{l}\text { Flag-tagged } \\
\text { Exogenous }\end{array}$ & $\begin{array}{l}\text { None } \\
\text { None }\end{array}$ & \begin{tabular}{|l} 
Affymetrix \\
U133 Plus 2.0 \\
array
\end{tabular} & $\begin{array}{l}\text { ND } \\
3 \% \text { total mRNA in multi- } \\
\text { complex granules; } 352 \\
\text { mRNAs } \\
(>3 x \text { enriched, } p<0.05)\end{array}$ \\
\hline $\begin{array}{l}\text { Hafner et } \\
\text { al } 2010 \\
\text { (5) }\end{array}$ & PAR-CLIP & $\begin{array}{l}>10^{8} \\
293 \mathrm{~T} \text { cells }\end{array}$ & $\begin{array}{l}\text { Flag/HA- } \\
\text { tagged } \\
\text { Exogenous }\end{array}$ & $\begin{array}{l}\text { UV Xlink } \\
\text { Labeling in } \\
\text { vivo with 4SU; } \\
\text { labeled in vitro } \\
\text { with }{ }^{32} \mathrm{P}\end{array}$ & $\begin{array}{l}\text { Solexa } \\
\text { sequencing of } \\
\text { cDNA library; } \\
\text { ID of } \\
\text { interacting } \\
\text { sequences }\end{array}$ & $\begin{array}{l}\text { ND } \\
56 \text { mRNAs (+19 mRNAs } \\
\text { encoded by mitochondrial } \\
\text { genome) }\end{array}$ \\
\hline $\begin{array}{l}\text { Barnes et } \\
\text { al } 2015 \\
(60)\end{array}$ & RIP & $\begin{array}{l}\approx 10^{6} \\
\text { HeLa } \\
\text { cells }\end{array}$ & $\begin{array}{l}\text { Flag/HA- } \\
\text { tagged } \\
\text { mouse } \\
\text { sequence } \\
\text { Exogenous }\end{array}$ & $\begin{array}{l}\text { None } \\
\text { None }\end{array}$ & $\begin{array}{l}\text { Site directed } \\
\text { mutagenesis } \\
\text { of CRD-BP; } \\
\text { focus on three } \\
\text { binding } \\
\text { partners, } \\
\text { CD44, c-myc } \\
\text { and } \beta \text {-actin }\end{array}$ & $\begin{array}{l}\text { ND } \\
\text { Not known }\end{array}$ \\
\hline $\begin{array}{l}\text { Conway } \\
\text { et al } 2016 \\
\text { (7) } \\
\text { Lambert } \\
\text { et al } 2014 \\
\text { (61) }\end{array}$ & \begin{tabular}{|l} 
eCLIP \\
\end{tabular} & $\begin{array}{l}2 \times 10^{7} \\
\text { hESC } \\
\text { cells }\end{array}$ & $\begin{array}{l}\text { Endogenous } \\
\text { Flag-tagged } \\
\text { Exogenous }\end{array}$ & $\begin{array}{l}\text { UV Xlink } \\
\text { Labeling in } \\
\text { vivo with 4SU; } \\
\text { labeled in vitro } \\
\text { with }{ }^{32} \mathrm{P}\end{array}$ & $\begin{array}{l}\text { Comparison } \\
\text { of eCLIP and } \\
\text { RBNS hits }\end{array}$ & $\begin{array}{l}\text { ND } \\
\text { Not known }\end{array}$ \\
\hline $\begin{array}{l}\text { This } \\
\text { study }\end{array}$ & $\begin{array}{l}\text { RIP with } \\
\text { ESP }\end{array}$ & $\begin{array}{l}<10^{6} \\
293 \mathrm{~T} \text { or } \\
\text { mammary } \\
\text { epithelial } \\
\text { cells }\end{array}$ & $\begin{array}{l}\text { Endogenous } \\
\text { Flag-tagged } \\
\text { Exogenous }\end{array}$ & None & $\begin{array}{l}\text { Nimblegen } \\
\text { array }\end{array}$ & $\begin{array}{l}\text { 50-90\% IGF2BP1 protein } \\
\text { 900 RNA species enriched } \\
(\mathrm{p}<0.05)\end{array}$ \\
\hline
\end{tabular}


bioRxiv preprint doi: https://doi.org/10.1101/2021.06.10.447893; this version posted June 10, 2021. The copyright holder for this preprint (which was not certified by peer review) is the author/funder, who has granted bioRxiv a license to display the preprint in perpetuity. It is made available under aCC-BY-NC 4.0 International license. 


\section{References}

1. Gerstberger, S., Hafner, M., Ascano, M., and Tuschl, T. (2014) Evolutionary conservation and expression of human RNA-binding proteins and their role in human genetic disease. Adv Exp Med Biol 825, $1-55$

2. Gerstberger, S., Hafner, M., and Tuschl, T. (2014) A census of human RNA-binding proteins. Nat Rev Genet 15, 829-845

3. Darnell, J. C., and Klann, E. (2013) The translation of translational control by FMRP: therapeutic targets for FXS. Nature neuroscience 16, 1530-1536

4. Vellky, J. E., McSweeney, S. T., Ricke, E. A., and Ricke, W. A. (2020) RNA-binding protein DDX3 mediates posttranscriptional regulation of androgen receptor: A mechanism of castration resistance. Proc Natl Acad Sci U S A 117, 28092-28101

5. Hafner, M., Landthaler, M., Burger, L., Khorshid, M., Hausser, J., Berninger, P., Rothballer, A., Ascano, M., Jungkamp, A. C., Munschauer, M., Ulrich, A., Wardle, G. S., Dewell, S., Zavolan, M., and Tuschl, T. (2010) PAR-CliP--a method to identify transcriptome-wide the binding sites of RNA binding proteins. $J$ Vis Exp

6. Eom, T., Antar, L. N., Singer, R. H., and Bassell, G. J. (2003) Localization of a beta-actin messenger ribonucleoprotein complex with zipcode-binding protein modulates the density of dendritic filopodia and filopodial synapses. J Neurosci 23, 10433-10444

7. Conway, A. E., Van Nostrand, E. L., Pratt, G. A., Aigner, S., Wilbert, M. L., Sundararaman, B., Freese, P., Lambert, N. J., Sathe, S., Liang, T. Y., Essex, A., Landais, S., Burge, C. B., Jones, D. L., and Yeo, G. W. (2016) Enhanced CLIP Uncovers IMP Protein-RNA Targets in Human Pluripotent Stem Cells Important for Cell Adhesion and Survival. Cell Rep 15, 666-679

8. Mili, S., and Steitz, J. A. (2004) Evidence for reassociation of RNA-binding proteins after cell lysis: implications for the interpretation of immunoprecipitation analyses. Rna 10, 1692-1694

9. Zeliadt, N. (2014) Capturing Complexes: Techniques for analyzing RNA-protein interactions. The Scientist October 2014

10. Van Nostrand, E. L., Huelga, S. C., and Yeo, G. W. (2016) Experimental and Computational Considerations in the Study of RNA-Binding Protein-RNA Interactions. Adv Exp Med Biol 907, 1-28

11. Ascano, M., Gerstberger, S., and Tuschl, T. (2013) Multi-disciplinary methods to define RNA-protein interactions and regulatory networks. Current opinion in genetics \& development 23, 20-28

12. Konig, J., Zarnack, K., Luscombe, N. M., and Ule, J. (2011) Protein-RNA interactions: new genomic technologies and perspectives. Nature reviews. Genetics 13, 77-83

13. Hansen, T. V., Hammer, N. A., Nielsen, J., Madsen, M., Dalbaeck, C., Wewer, U. M., Christiansen, J., and Nielsen, F. C. (2004) Dwarfism and impaired gut development in insulin-like growth factor II mRNA-binding protein 1-deficient mice. Mol Cell Biol 24, 4448-4464

14. Nielsen, J., Christiansen, J., Lykke-Andersen, J., Johnsen, A. H., Wewer, U. M., and Nielsen, F. C. (1999) A family of insulin-like growth factor II mRNA-binding proteins represses translation in late development. Mol Cell Biol 19, 1262-1270

15. Ross, A. F., Oleynikov, Y., Kislauskis, E. H., Taneja, K. L., and Singer, R. H. (1997) Characterization of a beta-actin mRNA zipcode-binding protein. Mol Cell Biol 17, 2158-2165

16. Bernstein, P. L., Herrick, D. J., Prokipcak, R. D., and Ross, J. (1992) Control of c-myc mRNA half-life in vitro by a protein capable of binding to a coding region stability determinant. Genes Dev 6, 642-654

17. Elcheva, I., Tarapore, R. S., Bhatia, N., and Spiegelman, V. S. (2008) Overexpression of mRNA-binding protein CRD-BP in malignant melanomas. Oncogene 27, 5069-5074 
18. Ross, J., Lemm, I., and Berberet, B. (2001) Overexpression of an mRNA-binding protein in human colorectal cancer. Oncogene 20, 6544-6550

19. Kobel, M., Weidensdorfer, D., Reinke, C., Lederer, M., Schmitt, W. D., Zeng, K., Thomssen, C., Hauptmann, S., and Huttelmaier, S. (2007) Expression of the RNA-binding protein IMP1 correlates with poor prognosis in ovarian carcinoma. Oncogene 26, 7584-7589

20. Doyle, G. A., Bourdeau-Heller, J. M., Coulthard, S., Meisner, L. F., and Ross, J. (2000) Amplification in human breast cancer of a gene encoding a $c$-myc mRNA-binding protein. Cancer Research 60, 27562759

21. Ioannidis, P., Mahaira, L. G., Papadopoulou, A., Teixeira, M. R., Heim, S., Andersen, J. A., Evangelou, E., Dafni, U., Pandis, N., and Trangas, T. (2003) 8q24 copy number gains and expression of the $c-m y c$ mRNA stabilizing protein $C R D-B P$ in primary breast carcinomas. International Journal of Cancer 104, 54-59

22. Fakhraldeen, S. A., Clark, R. J., Roopra, A., Chin, E. N., Huang, W., Castorino, J., Wisinski, K. B., Kim, T., Spiegelman, V. S., and Alexander, C. M. (2015) Two Isoforms of the RNA Binding Protein, Coding Region Determinant-binding Protein (CRD-BP/IGF2BP1), Are Expressed in Breast Epithelium and Support Clonogenic Growth of Breast Tumor Cells. J Biol Chem 290, 13386-13400

23. Buszczak, M., Signer, R. A., and Morrison, S. J. (2014) Cellular differences in protein synthesis regulate tissue homeostasis. Cell 159, 242-251

24. Chao, J. A., Patskovsky, Y., Patel, V., Levy, M., Almo, S. C., and Singer, R. H. (2010) ZBP1 recognition of beta-actin zipcode induces RNA looping. Genes \& development 24, 148-158

25. Farina, K. L., Huttelmaier, S., Musunuru, K., Darnell, R., and Singer, R. H. (2003) Two ZBP1 KH domains facilitate beta-actin mRNA localization, granule formation, and cytoskeletal attachment. J Cell Biol 160, 77-87

26. Sperger, J. M., Strotman, L. N., Welsh, A., Casavant, B. P., Chalmers, Z., Horn, S., Heninger, E., Thiede, S. M., Tokar, J., Gibbs, B. K., Guckenberger, D. J., Carmichael, L., Dehm, S. M., Stephens, P. J., Beebe, D. J., Berry, S. M., and Lang, J. M. (2017) Integrated Analysis of Multiple Biomarkers from Circulating Tumor Cells Enabled by Exclusion-Based Analyte Isolation. Clin Cancer Res 23, 746-756

27. Kipp, A. P. (2017) Selenium-Dependent Glutathione Peroxidases During Tumor Development. Adv Cancer Res 136, 109-138

28. Noubissi, F. K., Elcheva, I., Bhatia, N., Shakoori, A., Ougolkov, A., Liu, J., Minamoto, T., Ross, J., Fuchs, S. Y., and Spiegelman, V. S. (2006) CRD-BP mediates stabilization of bTrCP1 and c-myc mRNA in response to b-catenin signaling. Nature 441, 898-901

29. Goel, S., Chin, E. N., Fakhraldeen, S. A., Berry, S. M., Beebe, D. J., and Alexander, C. M. (2012) Both LRP5 and LRP6 receptors are required to respond to physiological Wnt ligands in mammary epithelial cells and fibroblasts. J Biol Chem 287, 16454-16466

30. Berry, S. M., Chin, E. N., Jackson, S. S., Strotman, L. N., Goel, M., Thompson, N. E., Alexander, C. M., Miyamoto, S., Burgess, R. R., and Beebe, D. J. (2014) Weak protein-protein interactions revealed by immiscible filtration assisted by surface tension. Analytical biochemistry 447, 133-140

31. Berry, S. M., Regehr, K. J., Casavant, B. P., and Beebe, D. J. (2013) Automated operation of immiscible filtration assisted by surface tension (IFAST) arrays for streamlined analyte isolation. J Lab Autom 18, 206-211

32. Berry, S. M., Singh, C., Lang, J. D., Strotman, L. N., Alarid, E. T., and Beebe, D. J. (2014) Streamlining gene expression analysis: integration of co-culture and mRNA purification. Integr Biol (Camb) 6, 224231 
33. Berry, S. M., LaVanway, A. J., Pezzi, H. M., Guckenberger, D. J., Anderson, M. A., Loeb, J. M., and Beebe, D. J. (2014) HIV viral RNA extraction in wax immiscible filtration assisted by surface tension (IFAST) devices. J Mol Diagn 16, 297-304

34. Moussavi-Harami, S. F., Annis, D. S., Ma, W., Berry, S. M., Coughlin, E. E., Strotman, L. N., Maurer, L. M., Westphall, M. S., Coon, J. J., Mosher, D. F., and Beebe, D. J. (2013) Characterization of molecules binding to the $70 \mathrm{~K}$ N-terminal region of fibronectin by IFAST purification coupled with mass spectrometry. J Proteome Res 12, 3393-3404

35. Casavant, B. P., Guckenberger, D. J., Beebe, D. J., and Berry, S. M. (2014) Efficient sample preparation from complex biological samples using a sliding lid for immobilized droplet extractions. Anal Chem 86, 6355-6362

36. Jonson, L., Vikesaa, J., Krogh, A., Nielsen, L. K., Hansen, T., Borup, R., Johnsen, A. H., Christiansen, J., and Nielsen, F. C. (2007) Molecular composition of IMP1 ribonucleoprotein granules. Mol Cell Proteomics 6, 798-811

37. Hafner, M., Landthaler, M., Burger, L., Khorshid, M., Hausser, J., Berninger, P., Rothballer, A., Ascano, M., Jr., Jungkamp, A. C., Munschauer, M., Ulrich, A., Wardle, G. S., Dewell, S., Zavolan, M., and Tuschl, T. (2010) Transcriptome-wide identification of RNA-binding protein and microRNA target sites by PAR-CLIP. Cell 141, 129-141

38. Devaux, F., Lelandais, G., Garcia, M., Goussard, S., and Jacq, C. (2010) Posttranscriptional control of mitochondrial biogenesis: spatio-temporal regulation of the protein import process. FEBS letters $\mathbf{5 8 4}$, 4273-4279

39. Berry, S. M., Alarid, E. T., and Beebe, D. J. (2011) One-step purification of nucleic acid for gene expression analysis via Immiscible Filtration Assisted by Surface Tension (IFAST). Lab Chip 11, 17471753

40. Berry, S. M., Chin, E. N., Jackson, S. S., Strotman, L. N., Goel, M., Thompson, N. E., Alexander, C. M., Miyamoto, S., Burgess, R. R., and Beebe, D. J. (2014) Weak protein-protein interactions revealed by immiscible filtration assisted by surface tension. Anal Biochem 447, 133-140

41. Sundararaman, B., Zhan, L., Blue, S. M., Stanton, R., Elkins, K., Olson, S., Wei, X., Van Nostrand, E. L., Pratt, G. A., Huelga, S. C., Smalec, B. M., Wang, X., Hong, E. L., Davidson, J. M., Lecuyer, E., Graveley, B. R., and Yeo, G. W. (2016) Resources for the Comprehensive Discovery of Functional RNA Elements. Mol Cell 61, 903-913

42. Van Nostrand, E. L., Pratt, G. A., Shishkin, A. A., Gelboin-Burkhart, C., Fang, M. Y., Sundararaman, B., Blue, S. M., Nguyen, T. B., Surka, C., Elkins, K., Stanton, R., Rigo, F., Guttman, M., and Yeo, G. W. (2016) Robust transcriptome-wide discovery of RNA-binding protein binding sites with enhanced CLIP (eCLIP). Nat Methods 13, 508-514

43. Keene, J. D., Komisarow, J. M., and Friedersdorf, M. B. (2006) RIP-Chip: the isolation and identification of mRNAs, microRNAs and protein components of ribonucleoprotein complexes from cell extracts. Nat Protoc 1, 302-307

44. Ascano, M., Hafner, M., Cekan, P., Gerstberger, S., and Tuschl, T. (2012) Identification of RNA-protein interaction networks using PAR-CLIP. Wiley Interdiscip Rev RNA 3, 159-177

45. Hafner, M., Lianoglou, S., Tuschl, T., and Betel, D. (2012) Genome-wide identification of miRNA targets by PAR-CLIP. Methods 58, 94-105

46. Scheibe, M., Butter, F., Hafner, M., Tuschl, T., and Mann, M. (2012) Quantitative mass spectrometry and PAR-CLIP to identify RNA-protein interactions. Nucleic Acids Res 40, 9897-9902

47. Spitzer, J., Hafner, M., Landthaler, M., Ascano, M., Farazi, T., Wardle, G., Nusbaum, J., Khorshid, M., Burger, L., Zavolan, M., and Tuschl, T. (2014) PAR-CLIP (Photoactivatable Ribonucleoside-Enhanced 
Crosslinking and Immunoprecipitation): a step-by-step protocol to the transcriptome-wide identification of binding sites of RNA-binding proteins. Methods Enzymol 539, 113-161

48. Bell, J. L., Wachter, K., Muhleck, B., Pazaitis, N., Kohn, M., Lederer, M., and Huttelmaier, S. (2013) Insulin-like growth factor 2 mRNA-binding proteins (IGF2BPs): post-transcriptional drivers of cancer progression? Cellular and molecular life sciences : CMLS 70, 2657-2675

49. Rackham, O., and Brown, C. M. (2004) Visualization of RNA-protein interactions in living cells: FMRP and IMP1 interact on mRNAs. The EMBO journal 23, 3346-3355

50. Ascano, M., Jr., Mukherjee, N., Bandaru, P., Miller, J. B., Nusbaum, J. D., Corcoran, D. L., Langlois, C., Munschauer, M., Dewell, S., Hafner, M., Williams, Z., Ohler, U., and Tuschl, T. (2012) FMRP targets distinct mRNA sequence elements to regulate protein expression. Nature 492, 382-386

51. Yang, F., Xue, X., Zheng, L., Bi, J., Zhou, Y., Zhi, K., Gu, Y., and Fang, G. (2014) Long non-coding RNA GHET1 promotes gastric carcinoma cell proliferation by increasing c-Myc mRNA stability. Febs $J$ 281, 802-813

52. Elcheva, I., Goswami, S., Noubissi, F. K., and Spiegelman, V. S. (2009) CRD-BP protects the coding region of betaTrCP1 mRNA from miR-183-mediated degradation. Molecular cell 35, 240-246

53. Weidensdorfer, D., Stohr, N., Baude, A., Lederer, M., Kohn, M., Schierhorn, A., Buchmeier, S., Wahle, E., and Huttelmaier, S. (2009) Control of c-myc mRNA stability by IGF2BP1-associated cytoplasmic RNPs. Rna 15, 104-115

54. Chen, E., Sharma, M. R., Shi, X., Agrawal, R. K., and Joseph, S. (2014) Fragile X mental retardation protein regulates translation by binding directly to the ribosome. Molecular cell 54, 407-417

55. Patel, V. L., Mitra, S., Harris, R., Buxbaum, A. R., Lionnet, T., Brenowitz, M., Girvin, M., Levy, M., Almo, S. C., Singer, R. H., and Chao, J. A. (2012) Spatial arrangement of an RNA zipcode identifies mRNAs under post-transcriptional control. Genes Dev 26, 43-53

56. Dimitriadis, E., Trangas, T., Milatos, S., Foukas, P. G., Gioulbasanis, I., Courtis, N., Nielsen, F. C., Pandis, N., Dafni, U., Bardi, G., and Ioannidis, P. (2007) Expression of oncofetal RNA-binding protein CRD-BP/IMP1 predicts clinical outcome in colon cancer. Int J Cancer 121, 486-494

57. Gu, W., Katz, Z., Wu, B., Park, H. Y., Li, D., Lin, S., Wells, A. L., and Singer, R. H. (2012) Regulation of local expression of cell adhesion and motility-related mRNAs in breast cancer cells by IMP1/ZBP1. Journal of cell science 125, 81-91

58. Hamilton, K. E., Noubissi, F. K., Katti, P. S., Hahn, C. M., Davey, S. R., Lundsmith, E. T., KleinSzanto, A. J., Rhim, A. D., Spiegelman, V. S., and Rustgi, A. K. (2013) IMP1 promotes tumor growth, dissemination and a tumor-initiating cell phenotype in colorectal cancer cell xenografts. Carcinogenesis 34, 2647-2654

59. Craig, E. A., Weber, J. D., and Spiegelman, V. S. (2012) Involvement of the mRNA binding protein CRD-BP in the regulation of metastatic melanoma cell proliferation and invasion by hypoxia. Journal of cell science

60. Barnes, M., van Rensburg, G., Li, W. M., Mehmood, K., Mackedenski, S., Chan, C. M., King, D. T., Miller, A. L., and Lee, C. H. (2015) Molecular insights into the coding region determinant-binding protein-RNA interaction through site-directed mutagenesis in the heterogeneous nuclear ribonucleoprotein-K-homology domains. J Biol Chem 290, 625-639

61. Lambert, N., Robertson, A., Jangi, M., McGeary, S., Sharp, P. A., and Burge, C. B. (2014) RNA Bind-nSeq: quantitative assessment of the sequence and structural binding specificity of RNA binding proteins. Mol Cell 54, 887-900

62. Leeds, P., Kren, B. T., Boylan, J. M., Betz, N. A., Steer, C. J., Gruppuso, P. A., and Ross, J. (1997) Developmental regulation of CRD-BP, an RNA-binding protein that stabilizes c-myc mRNA in vitro. Oncogene 14, 1279-1286 
63. Woellhaf, M. W., Hansen, K. G., Garth, C., and Herrmann, J. M. (2014) Import of ribosomal proteins into yeast mitochondria. Biochem Cell Biol, 1-10

64. Dannenmann, B., Lehle, S., Hildebrand, D. G., Kubler, A., Grondona, P., Schmid, V., Holzer, K., Froschl, M., Essmann, F., Rothfuss, O., and Schulze-Osthoff, K. (2015) High glutathione and glutathione peroxidase-2 levels mediate cell-type-specific DNA damage protection in human induced pluripotent stem cells. Stem Cell Reports 4, 886-898

65. Nishino, J., Kim, S., Zhu, Y., Zhu, H., and Morrison, S. J. (2013) A network of heterochronic genes including Imp1 regulates temporal changes in stem cell properties. elife 2, e00924

66. Son, M. J., Ryu, J. S., Kim, J. Y., Kwon, Y., Chung, K. S., Mun, S. J., and Cho, Y. S. (2017) Upregulation of mitochondrial NAD $(+)$ levels impairs the clonogenicity of SSEA1(+) glioblastoma tumor-initiating cells. Exp Mol Med 49, e344

67. Pla-Martin, D., Schatton, D., Wiederstein, J. L., Marx, M. C., Khiati, S., Kruger, M., and Rugarli, E. I. (2020) CLUH granules coordinate translation of mitochondrial proteins with mTORC1 signaling and mitophagy. EMBO J 39, e102731

68. Wu, W., Li, D., Feng, X., Zhao, F., Li, C., Zheng, S., and Lyu, J. (2021) A pan-cancer study of selenoprotein genes as promising targets for cancer therapy. BMC Med Genomics 14, 78

69. Lederer, M., Bley, N., Schleifer, C., and Huttelmaier, S. (2014) The role of the oncofetal IGF2 mRNAbinding protein 3 (IGF2BP3) in cancer. Semin Cancer Biol 29, 3-12

70. Faye, M. D., Beug, S. T., Graber, T. E., Earl, N., Xiang, X., Wild, B., Langlois, S., Michaud, J., Cowan, K. N., Korneluk, R. G., and Holcik, M. (2015) IGF2BP1 controls cell death and drug resistance in rhabdomyosarcomas by regulating translation of cIAP1. Oncogene 34, 1532-1541

71. Kloetgen, A., Munch, P. C., Borkhardt, A., Hoell, J. I., and McHardy, A. C. (2015) Biochemical and bioinformatic methods for elucidating the role of RNA-protein interactions in posttranscriptional regulation. Brief Funct Genomics 14, 102-114

72. Burger, K., Muhl, B., Kellner, M., Rohrmoser, M., Gruber-Eber, A., Windhager, L., Friedel, C. C., Dolken, L., and Eick, D. (2013) 4-thiouridine inhibits rRNA synthesis and causes a nucleolar stress response. RNA Biol 10, 1623-1630 
Figure 1

A Ribonucleoprotein Immunoprecipitation Exclusion-Based Sample Preparation (RIP-ESP)

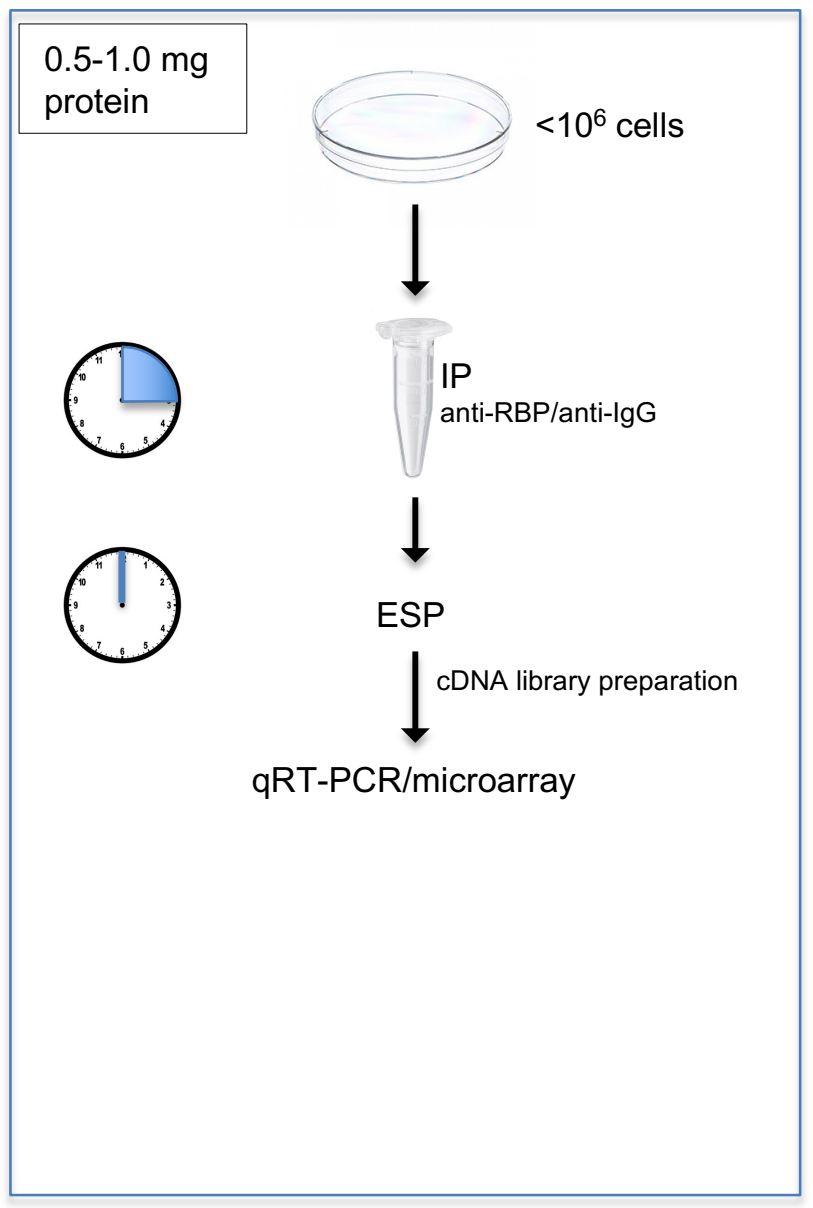

B Photoactivatable-Ribonucleoside-Enhanced Crosslinking and Immunoprecipitation (PAR-CLIP)

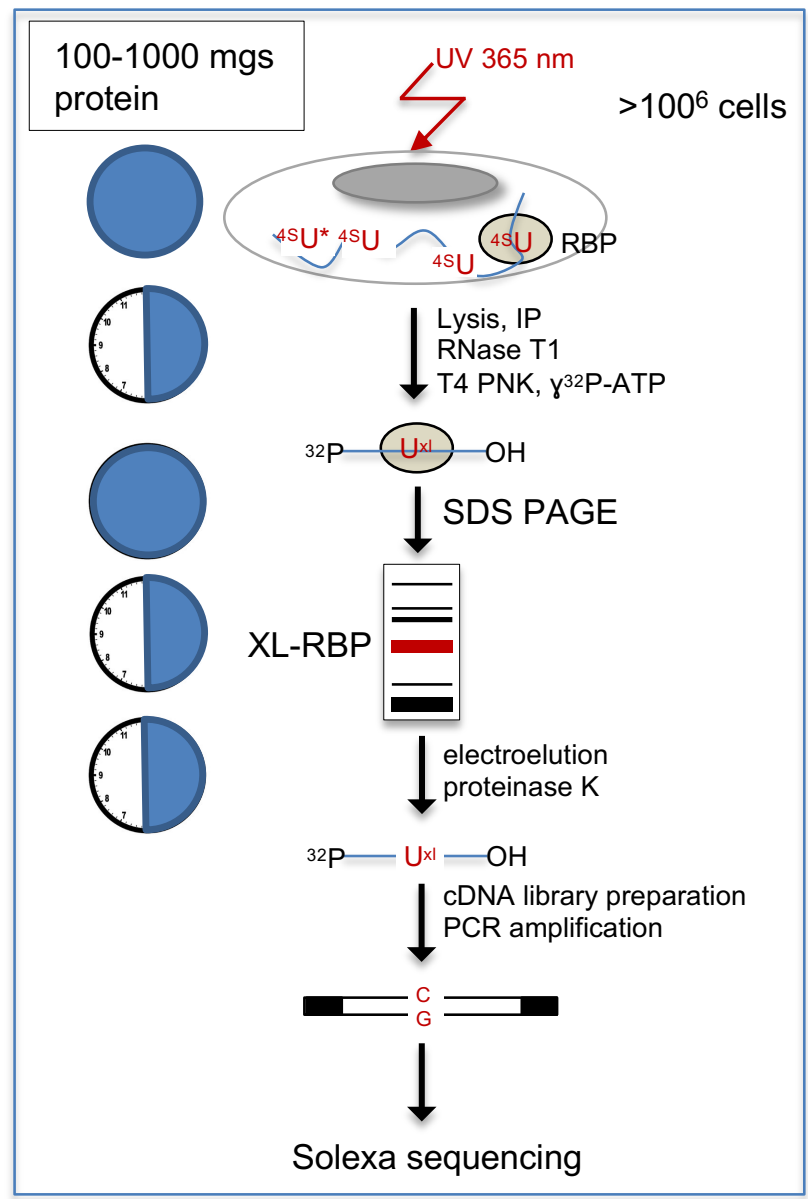


Figure 2

A

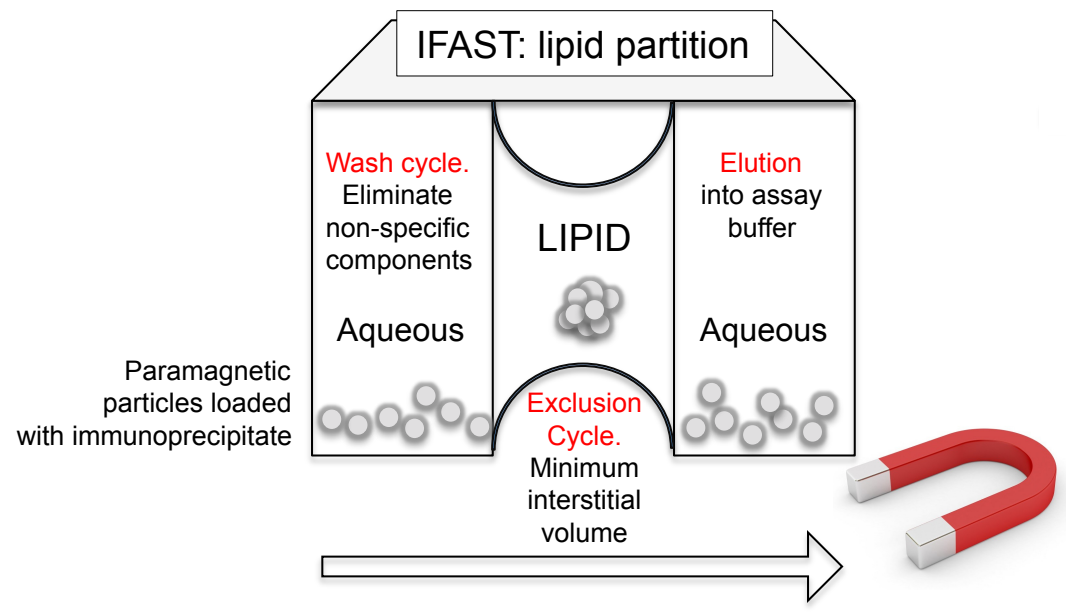

B

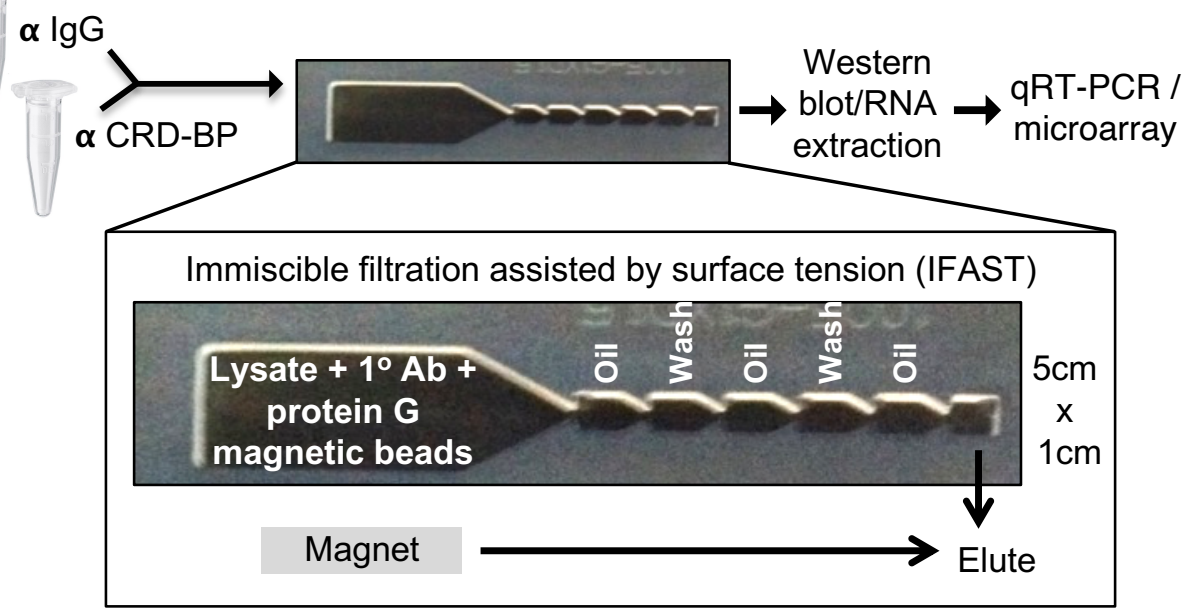


Figure 3

A

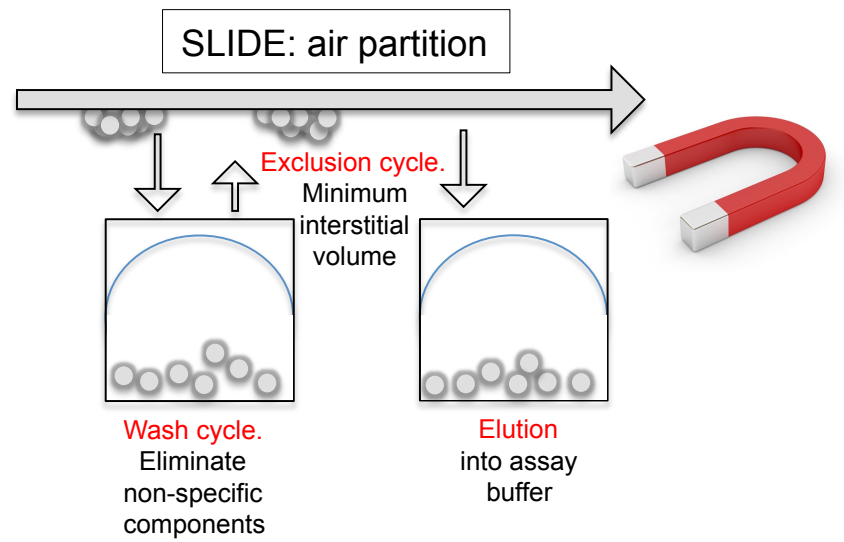

B

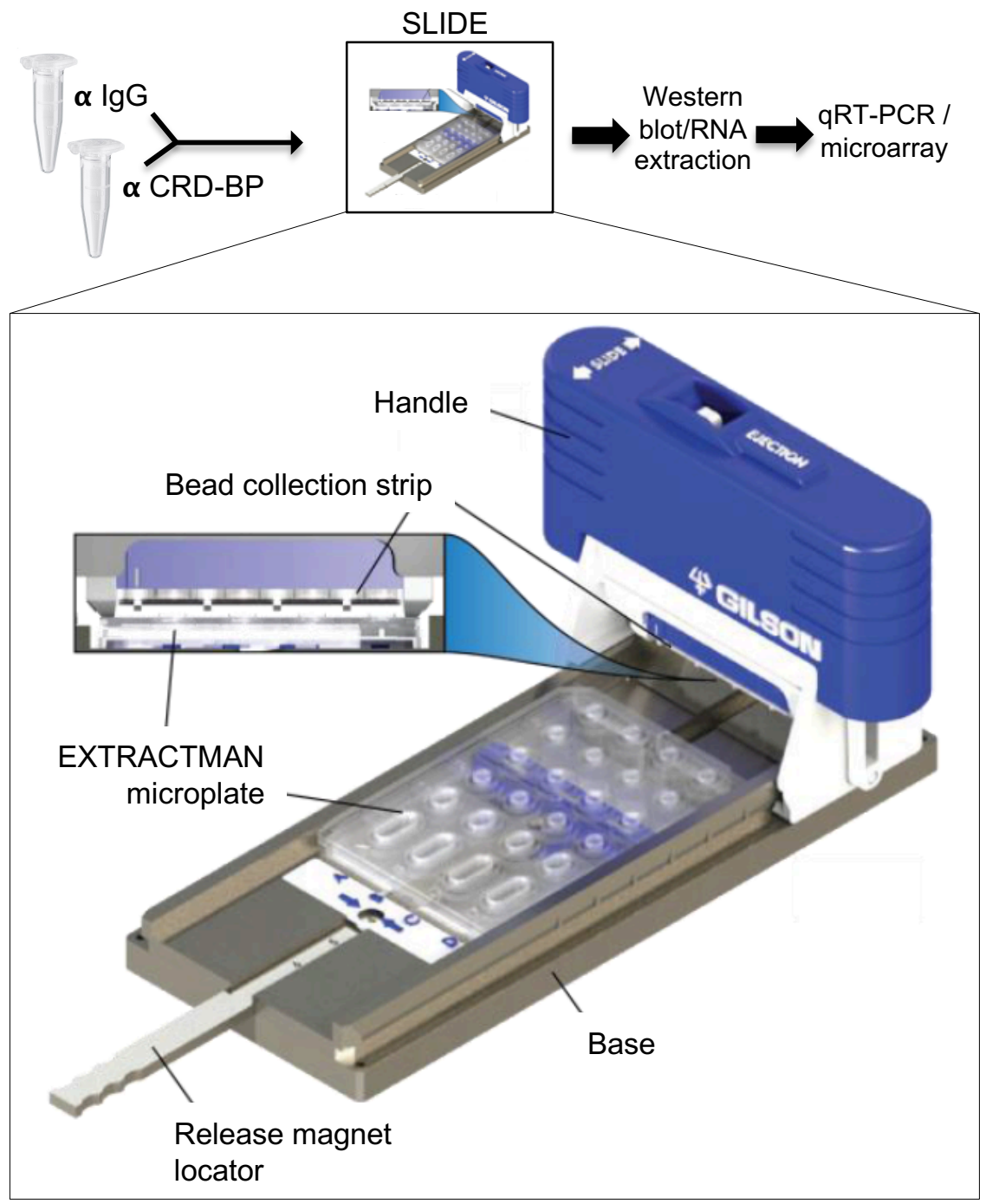




\section{Figures1-8}

Figure 4

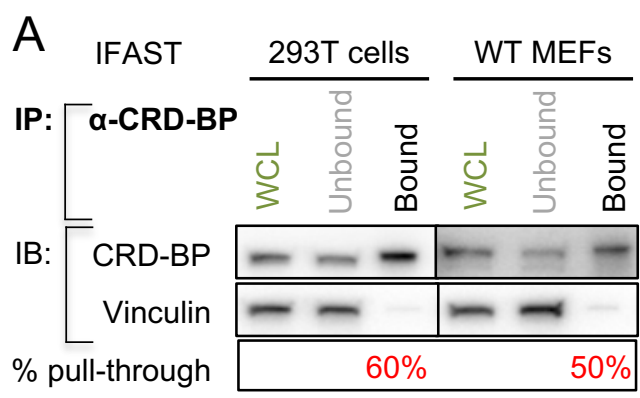

B IFAS

EP cells

EN cells

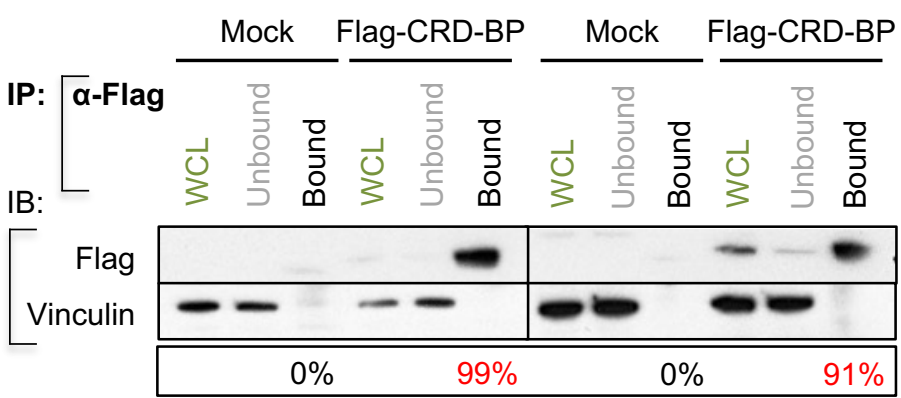

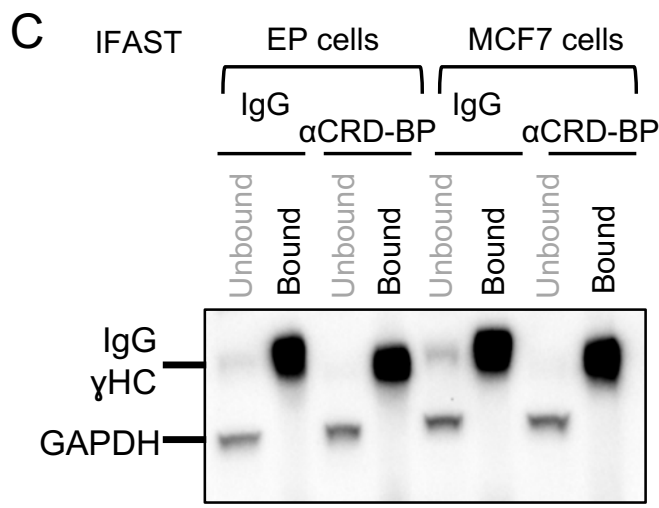

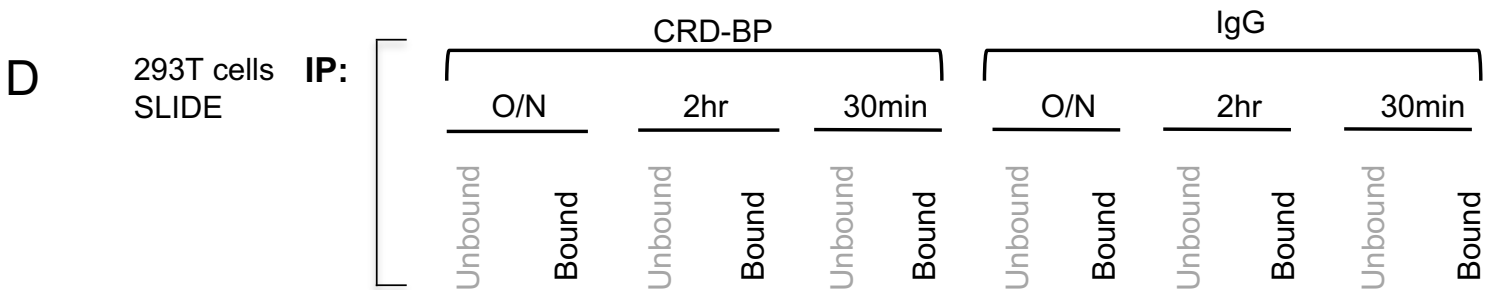

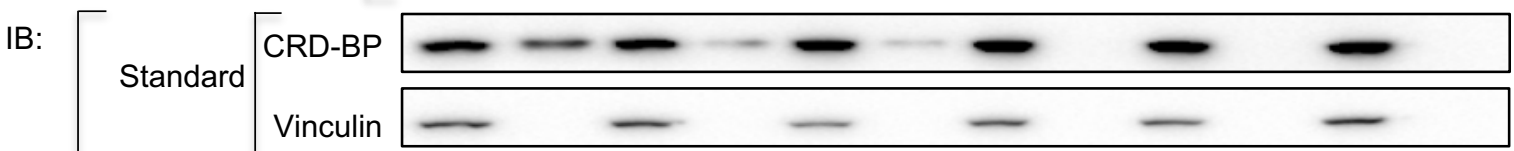

\begin{tabular}{llll|lll|} 
& $\%$ pull-through \\
\cline { 2 - 5 } & $37 \%$ & $19 \%$ & $13 \%$ & $0 \%$ & $0 \%$ & $0 \%$ \\
\hline
\end{tabular}

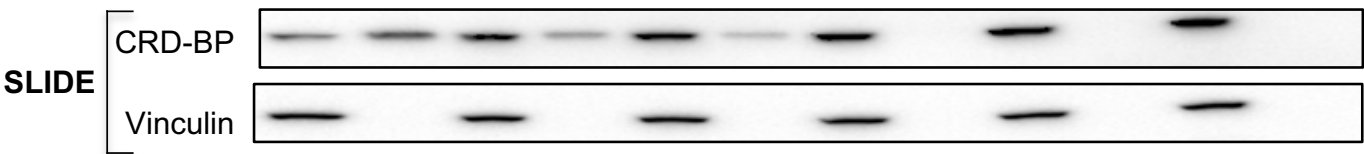

$\%$ pull-through

$60 \%$

$33 \% \quad 24 \%$

$0 \%$

$0 \%$

$0 \%$ 


\section{Figures1-8}

Figure 5

A

Mouse MECs (EP)

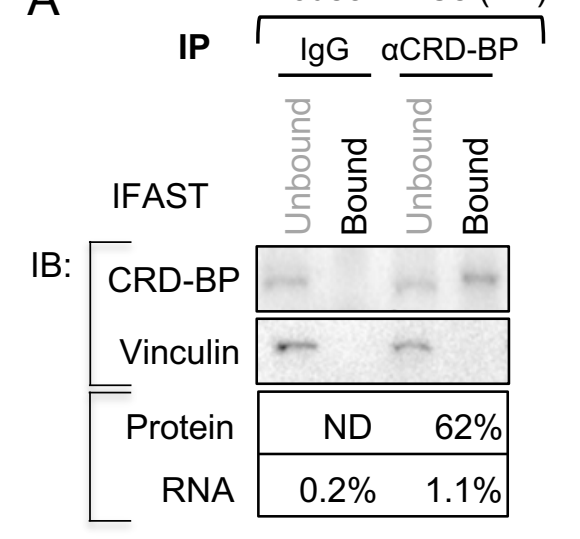

Fraction

Total RNA RNA pull-through

$(\mu g)$

efficiency

\begin{tabular}{|c|c|c|c|}
\hline \multirow{2}{*}{$\lg$ Ig } & Unbound & 45 & \multirow{2}{*}{$0.2 \pm 0.03 \%$} \\
\cline { 2 - 3 } & Bound & 0.09 & \\
\hline \multirow{2}{*}{ a-CRD-BP } & Unbound & 30 & \multirow{2}{*}{$1.1 \pm 0.12 \%$} \\
\cline { 2 - 3 } & Bound & 0.34 & \\
\hline
\end{tabular}

5x enrichment

B

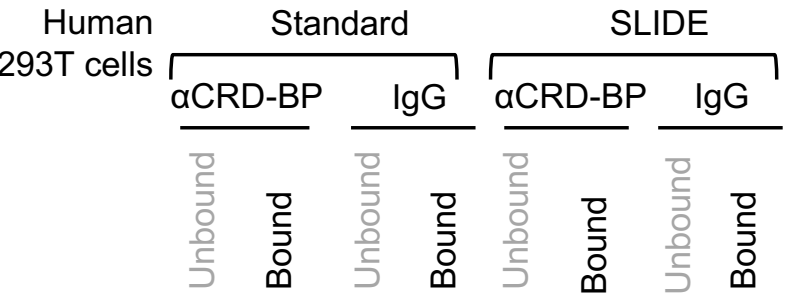

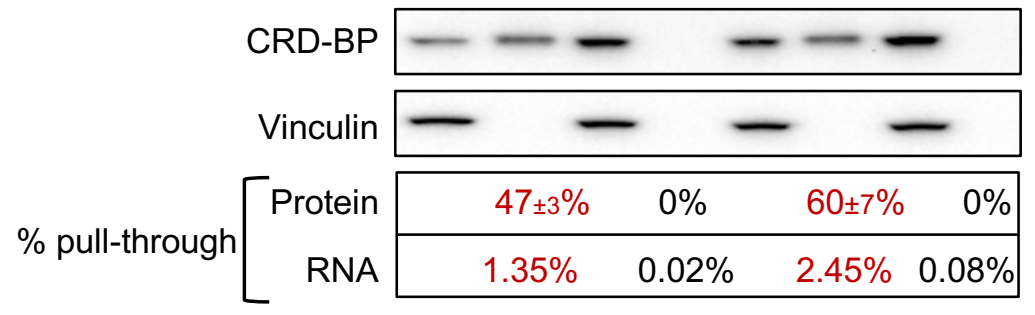

C

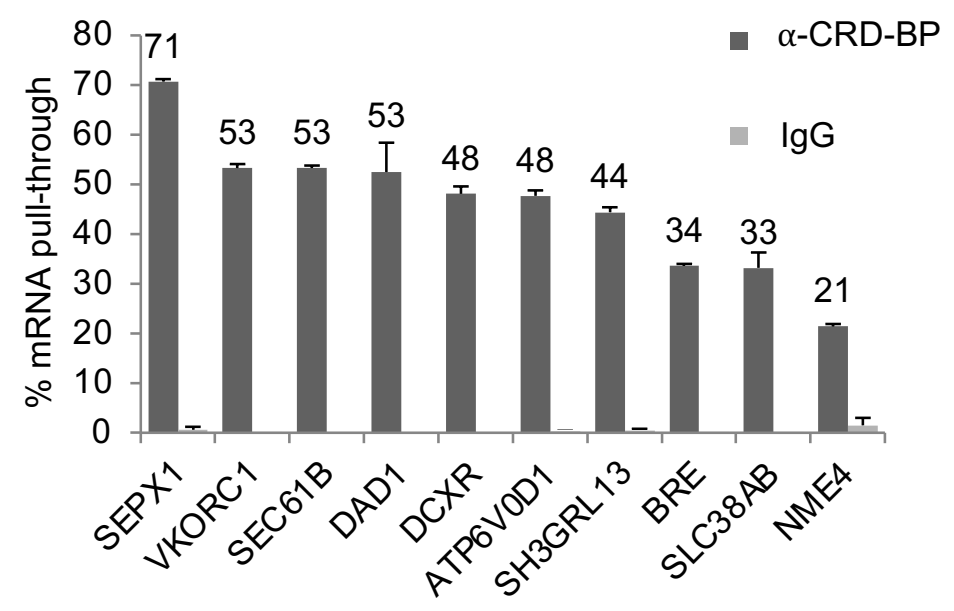


Figure 6

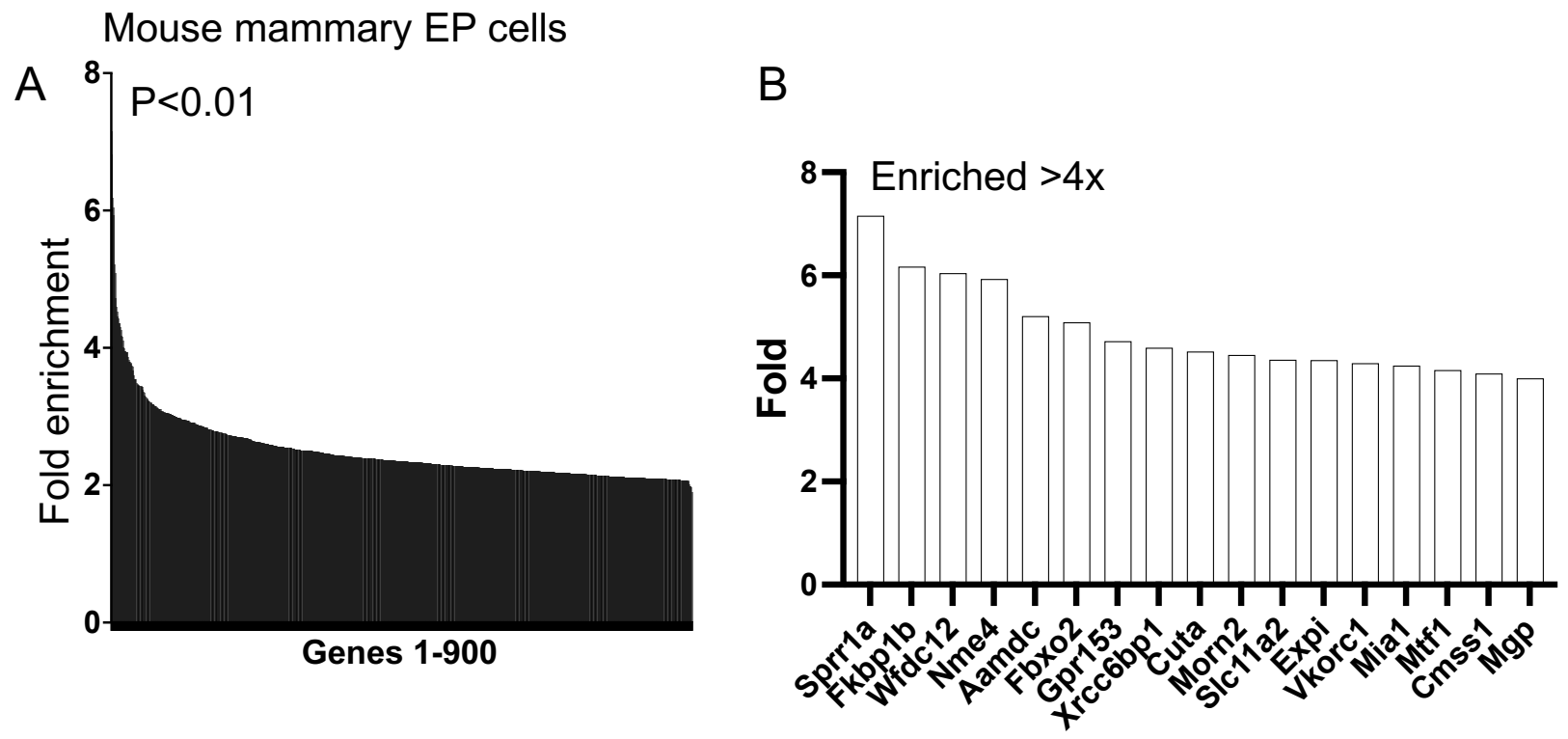

C

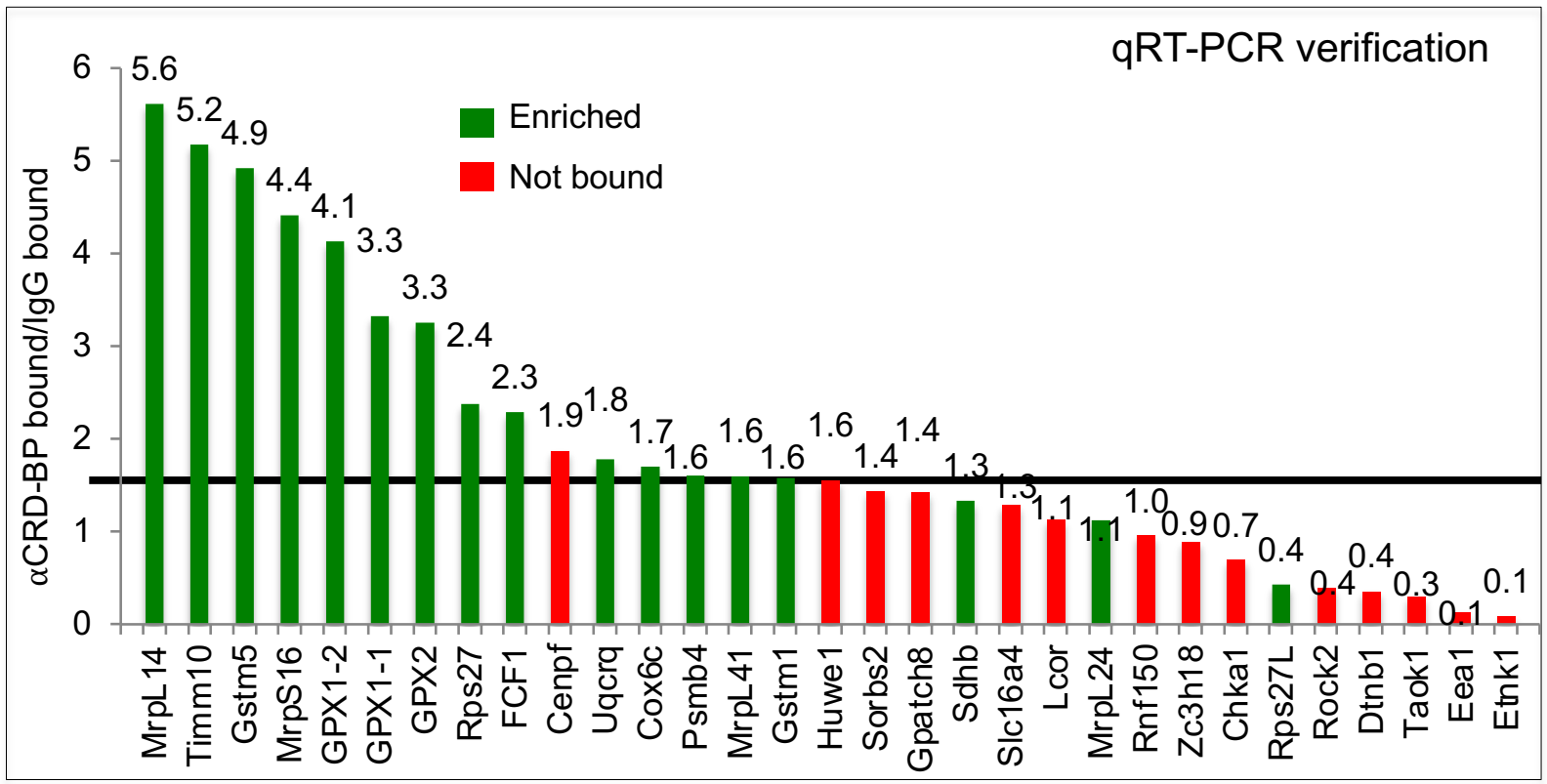




\section{A. Control lgG}

Histones
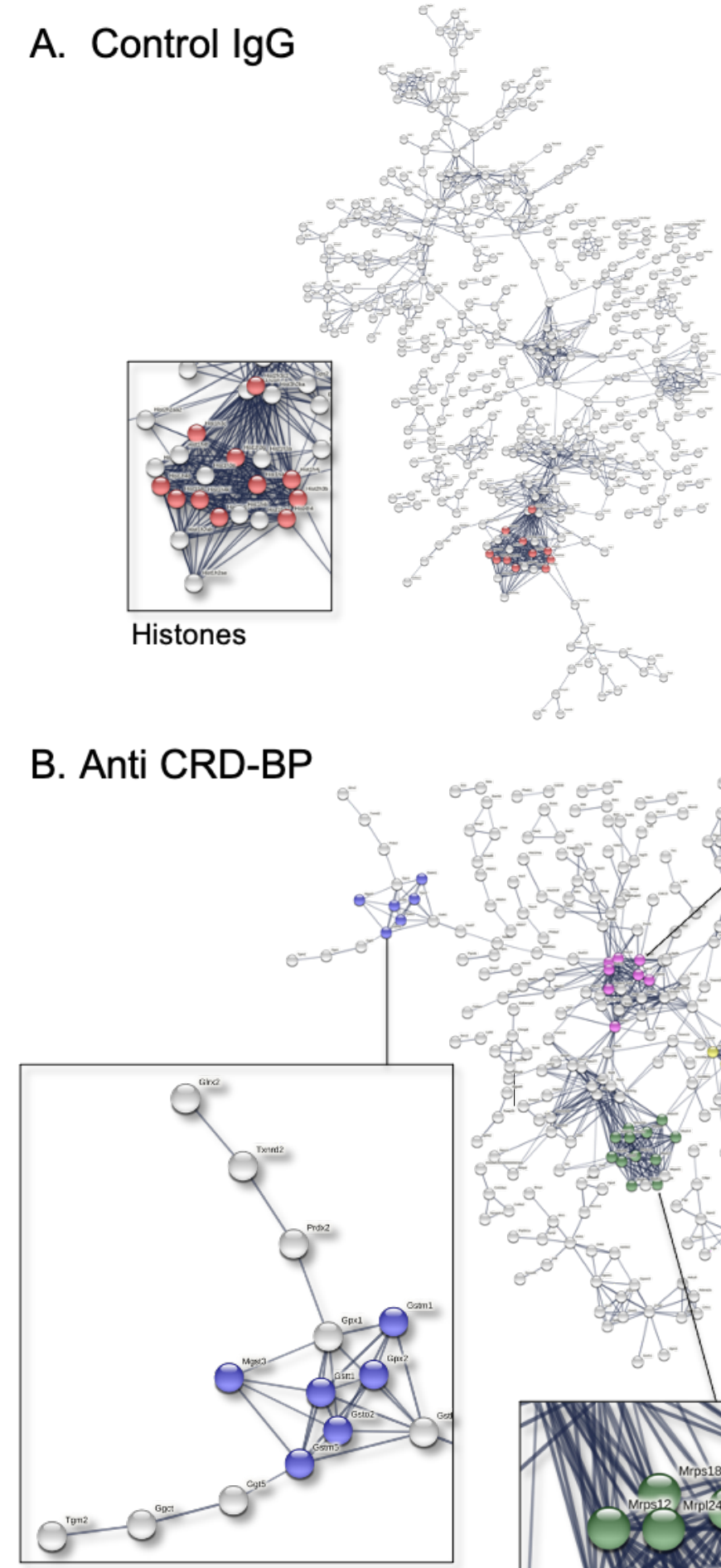

Glutathione
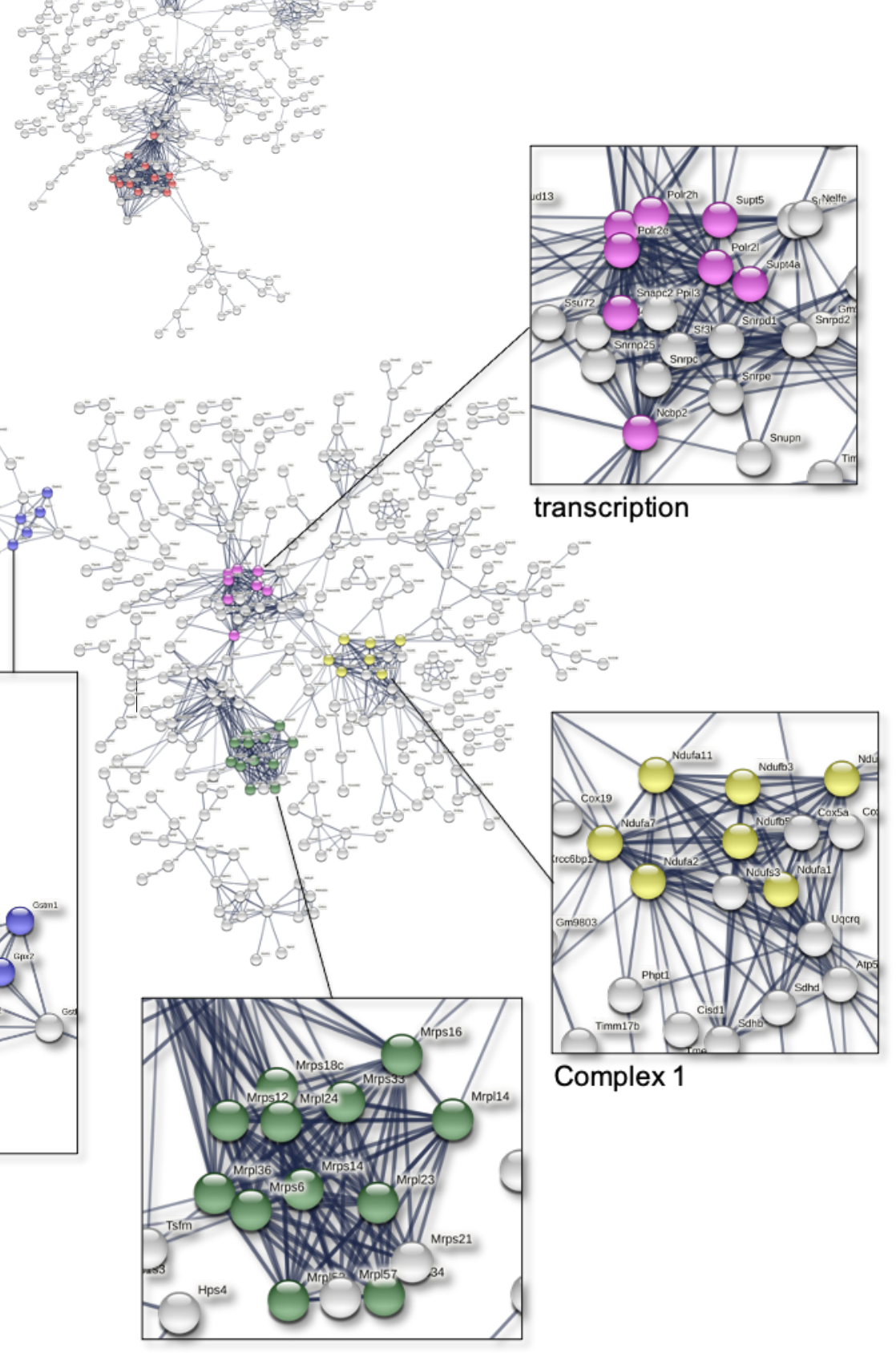

Mitochondrial translation 
Figure 8
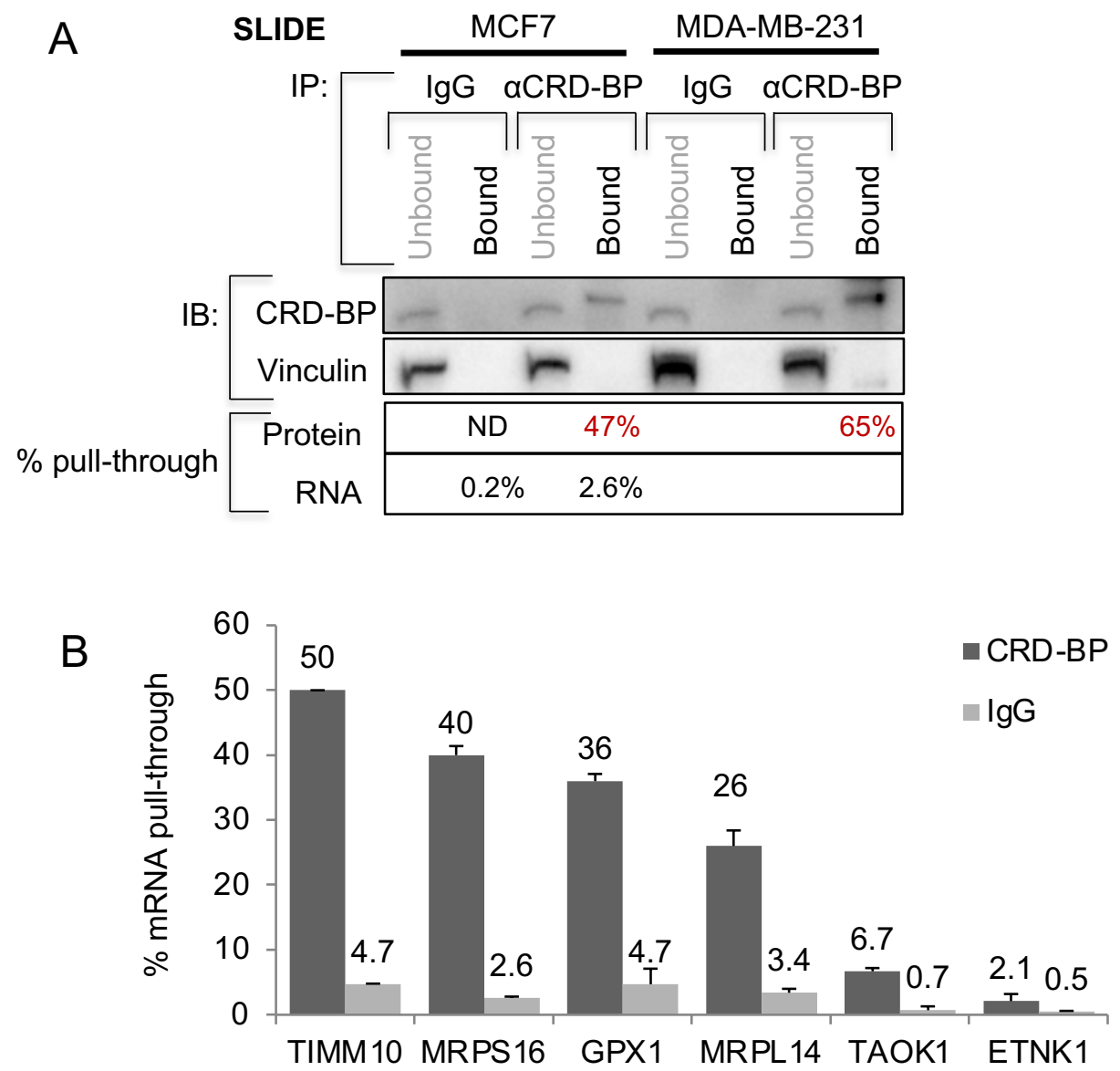